\title{
Transport pathways of decapod larvae under intense mesoscale activity in the Canary-African coastal transition zone: implications for population connectivity
}

\author{
José M. Landeira ${ }^{1}$, Timothée Brochier ${ }^{2}$, Evan Mason ${ }^{3}$, Fernando Lozano-Soldevilla ${ }^{4}$, \\ Santiago Hernández-León ${ }^{5}$, Eric D. Barton ${ }^{6}$ \\ ${ }^{1}$ Department of Ocean Sciences, Tokyo University of Marine Science and Technology, 4-5-7 Konan, Minato, \\ Tokyo 108-8477, Japan. \\ (JML) (Corresponding author) E-mail: jm_landeira@yahoo.es. ORCID iD: http://orcid.org/0000-0001-6419-2046 \\ ${ }^{2}$ Institut de Recherche pour le Développement (IRD), Unité de Modélisation Mathématique et Informatique des Systèmes \\ Complexes (UMMISCO), UMI 209, Univ Paris 06, Sorbonne Universités, Bondy, France. \\ (TB) E-mail: Timothee.brochier@ird.fr. ORCID ID: http://orcid.org/0000-0002-6648-0516 \\ ${ }^{3}$ Mediterranean Institute for Advanced Studies (UIB-CSIC), C./Miquel Marquès 21, Esporles, Palma de Mallorca 07190, \\ Spain. (EM) E-mail: emason@imedea.uib-csic.es. ORCID ID: http://orcid.org/0000-0002-2283-6285 \\ ${ }^{4}$ Departamento de Biología Animal, Edafología y Geología. Universidad de La Laguna, Avd. Astrofísico Francisco \\ Sánchez, s/n. 38200 La Laguna, Spain. \\ (FL-S) E-mail: flozano@ull.edu.es. ORCID ID: http://orcid.org/0000-0002-1028-4356 \\ ${ }^{5}$ Instituto de Oceanografía y Cambio Global (IOCAG), Universidad de Las Palmas de Gran Canaria. Campus Universitario \\ de Tafira, 35017 Las Palmas de Gran Canaria, Spain. \\ (SH-L) E-mail: shernandezleon@ulpgc.es. ORCID ID: http://orcid.org/0000-0002-3085-4969 \\ ${ }^{6}$ Departamento de Oceanografía, Instituto de Investigaciones Marinas (IIM), CSIC, 36208, Vigo, Spain. \\ (EDB) E-mail: barton@iim.csic.es. ORCID ID: http://orcid.org/0000-0002-5315-5968
}

\begin{abstract}
Summary: We investigate the transport dynamics of decapod larvae in the Canary-African coastal transition zone (CACTZ), where larval assemblages are poorly known. In August 1999, during the FAX99 cruise, the waters downstream of the Canary Island archipelago displayed intense mesoscale activity, with numerous cyclonic and anticyclonic eddies as well as upwelling filaments. Our results illustrate a close relationship between these mesoscale oceanographic structures and the distribution of decapod larvae, using both field observations and Lagrangian transport modelling. Analysis of plankton samples shows that larvae of pelagic species were excluded from filament waters, whereas larvae of neritic species were heterogeneously distributed, suggesting that the C-ACTZ is a mixing area where larvae originating from both the Canary Islands and the African coast may be present at the same time. This finding was supported by the simulations, which suggested that the larvae collected in the offshore waters south of Gran Canaria came mainly from the African population (between Cape Bojador and Cape Juby) during early August, whereas during the second half of August the targeted area was dominated by larvae released from Fuerteventura populations. Our observations introduce new insights into our understanding of marine population connectivity, the dispersal pathways of the terrestrial biota, and general biogeography in the region.
\end{abstract}

Keywords: decapod larvae; C-ACTZ; upwelling filament; eddy; Lagrangian transport; connectivity.

Vías de transporte de larvas de decápodos en condiciones de intensa actividad mesoescalar en la región de transición canario-africana: implicaciones para la conectividad poblacional

Resumen: Investigamos la dinámica del transporte de larvas de decápodos en la región de transición canario-africana (CACTZ), donde el conocimiento sobre las asociaciones de larvas es escaso. En agosto de 1999, durante la campaña FAX99, las aguas al sur del Archipiélago Canario mostraron una intensa actividad mesoescalar a modo de numerosos remolinos ciclónicos y anticiclónicos, así como de filamentos de afloramiento. Nuestros resultados ilustran una relación estrecha entre las estructuras oceanográficas mesoescalares y la distribución de larvas de decápodos tanto mediante observaciones in situ como modelos de transporte larvario. El análisis de las muestras de plancton mostró la práctica ausencia de larvas de especies pelágicas en aguas asociadas al filamento de afloramiento, mientras que las larvas de especies neríticas mostraron una distribución heterogénea, lo que indica que la C-ACTZ es una zona de mezcla donde larvas con origen canario y africano pueden coexistir simultáneamente. Las simulaciones apoyaron estos patrones de distribución y sugieren que las larvas presentes en aguas abiertas al sur de Gran Canaria llegaron principalmente desde poblaciones africanas a principios de agosto, mientras que durante la segunda mitad del mes fueron larvas liberadas desde las poblaciones de Fuerteventura, las que dominaron la región de estudio. Nuestras observaciones introducen nuevos datos que contribuyen a una mejor comprensión de los patrones de conectividad en el medio marino, así como de las vías de dispersión de la biota marina y terrestre y la biogeografía global de la región.

Palabras clave: larvas de decápodos; C-ACTZ; filamentos de afloramiento; remolino; transporte lagrangiano; conectividad. 
Citation/Como citar este artículo: Landeira J.M., Brochier T., Mason E., Lozano-Soldevilla F., Hernández-León S., Barton E.D. 2017. Transport pathways of decapod larvae under intense mesoscale activity in the Canary-African coastal transition zone: implications for population connectivity. Sci. Mar. 81(3): 299-315. doi: http://dx.doi.org/10.3989/scimar.04599.06A

Editor: J. Salat.

Received: December 21, 2016. Accepted: May 31, 2017. Published: July 13, 2017.

Copyright: (C) 2017 CSIC. This is an open-access article distributed under the terms of the Creative Commons Attribution (CC-by) Spain 3.0 License.

\section{INTRODUCTION}

Larval transport is a key factor for dispersal capabilities of marine species (Pineda et al. 2007). Oceanographic structures such as eddies and filaments are associated with strong transports that influence larval fate. Studying these structures allows us to detect potential connectivity routes between distant populations, which are a useful tool for managing commercial species, designing marine protected areas, and monitoring the spread of invasive species (Underwood and Keough 2001). These routes are of special importance in recruitment-limited regions such as upwelling systems, where dispersive mechanisms can transport larvae offshore, reducing recruitment to natal populations (Roughgarden et al. 1988, Connolly et al. 2001). However, recent studies have shown that, even during strong upwelling conditions, retention processes prevent the offshore loss of larvae because the larvae of many nearshore invertebrates are found in highest abundance closest to shore and within the upwelling front (Shanks and Shearman 2009, Morgan et al. 2009, Morgan and Fisher 2010).

In our study area, within the Northwest African Upwelling (Fig. 1), the dynamics of decapod larvae is poorly studied in contrast with that of ichthyoplankton (Rodríguez et al. 2009). In recent decades, several multidisciplinary surveys have increased the understanding of oceanographic processes in the Canary-African Coastal Transition Zone (C-ACTZ), as well as their influence on the plankton community and fish larvae, but no attention has been paid to other taxonomic larval groups. The C-ACTZ is an area of strong mesoscale oceanographic activity (Barton et al. 1998, 2004, Sangrà et al. 2009). Remote sensing and field observations of temperature and chlorophyll have revealed that cyclonic and anticyclonic eddies are sequentially spun off from several islands in the Canary Archipelago all year long (Hernández-Guerra et al. 1993, Jiménez et al. 2008, Piedeleu et al. 2009). These eddies are generated as a perturbation of the southwestward-flowing Canary Current by the island's topography (Arístegui et al. 1997, Sangrà et al. 2007), favoured by the trade winds through Ekman pumping in the islands' wakes (Barton et al. 2000). Eddies have profound implications for the development and distribution of plankton in the C-ACTZ. Cyclonic eddy circulation pumps deep waters to the euphotic zone, enhancing phytoplankton primary production (Arístegui et al. 1997, Lasternas et al. 2013), and accumulates phyto- and mesozooplankton biomass at the eddy boundary (Arístegui et al. 1997, Hernández-León et al. 2001a). Conversely, anticyclonic eddies promote downwelling, deepening the mixed layer and sinking warmer oligotrophic surface water, bacteria and phytoplankton in their cores (Baltar et al. 2010, Lasternas et al. 2013). Moreover, eddies contribute to the larval retention of neritic species that have been advected from their island populations (Lobel and Robinson 1988, Rodríguez et al. 2001, Torres et al. 2014).

Upwelling filaments are another common mesoscale feature in this area. They are near-surface structures, tens of kilometres in width, which may extend up to several hundred kilometres in length, connecting the coastal upwelling with the open ocean. In the C-ACTZ, they originate between Cape Juby and Cape Bojador due to the presence of a quasi-permanent eddy trapped in the trough between the African shelf and the islands of Gran Canaria and Fuerteventura, which entrains water from the coastal jet, thus giving rise to a filament (Barton et al. 1998, 2004). Moreover, it is known that the combination of weak stratification, a wide continental shelf and persistent favourable winds can aid the formation of the filament near capes (Marchesiello and Estrade 2009). Filaments contribute to the mesoscale transport of nutrients (Jones et al. 1991), organic matter (García-Muñoz et al. 2004, Santana-Falcón et al. 2016), chlorophyll (Arístegui et al. 1997, Basterretxea et al. 2002) and mesozooplankton (Hernández-León et al. 2002a, Yebra et al. 2004) from the African coast to the open ocean. In the case of fish larvae, Rodríguez et al. (1999) proposed the filament-eddy combination as a favourable retention mechanism for African neritic species, but it can also produce significant larval advection towards the ocean domain (Rodríguez et al. 2004, Bécognée et al. 2009). Occasionally, these African larvae can reach the vicinity of the Canary Islands (Bécognée et al. 2006, Brochier et al. 2008, 2011, Moyano et al. 2009).

In this paper, we study the transport of decapod larvae related to the complex filament-eddy system of August 1999 in the C-ACTZ described by Barton et al. (2004). Although most of the larval pool seems to be retained in the nearshore of the islands and the African coast by specific retention mechanisms, there is some evidence that larvae of neritic decapod species are distributed to open waters of the C-ACTZ. Previous studies in the area have shown that larvae are advected around eddies south of Gran Canaria (Landeira et al. 2009,2010 ) and within a filament spread from the African upwelling (Landeira et al. 2012). Therefore, the aim of this study was to examine advection and retention processes in the $\mathrm{C}$-ACTZ and explore the coupling between oceanographic conditions and larval distribution through field observations and transport modelling. Further, we discuss the likely dispersal routes 

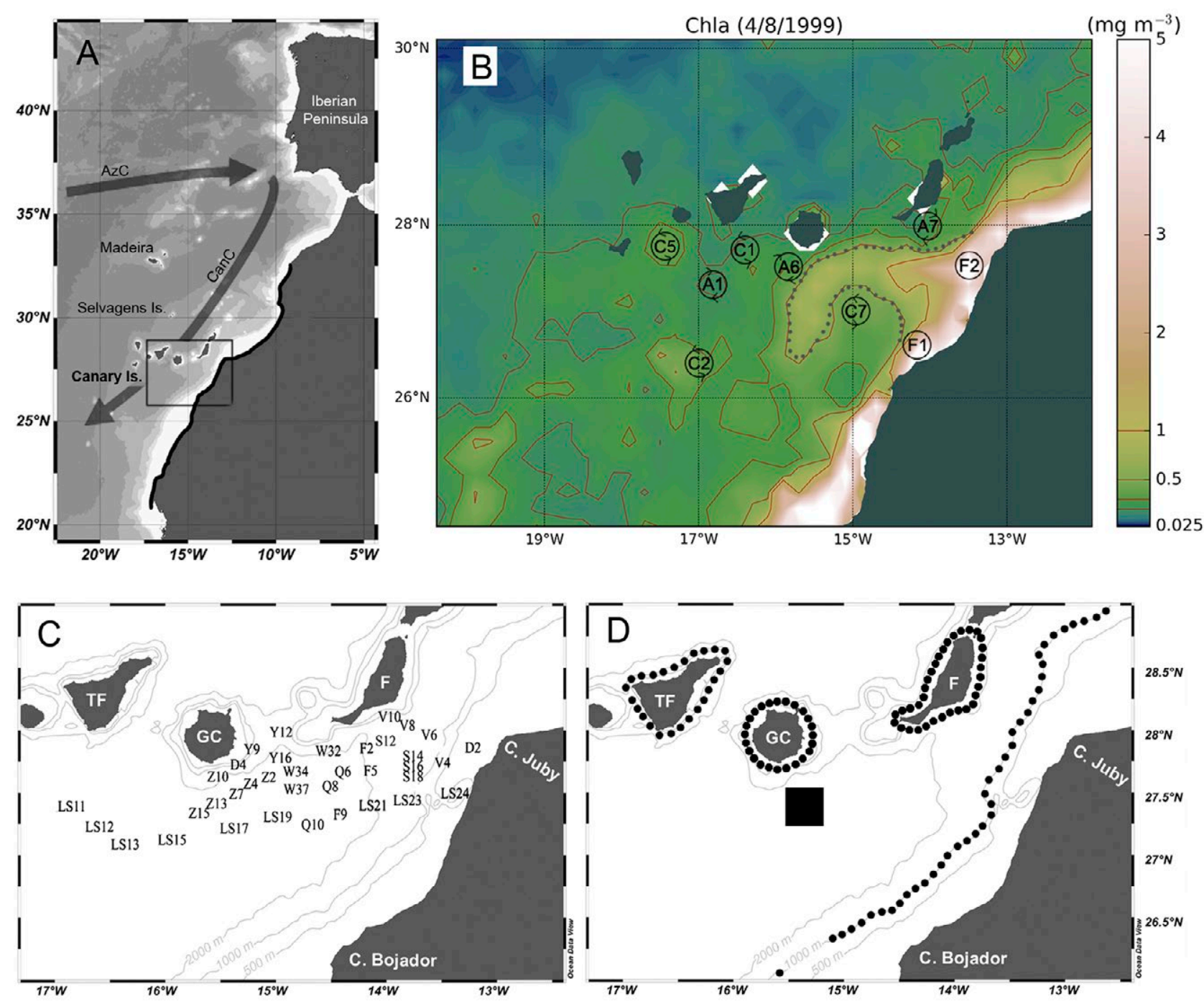

Fig. 1. - Map of the study area off the NE Atlantic region. A, the principal currents of the eastern subtropical gyre are shown: Azores Current, AzC; Canary Current, CanC. B, SeaWIFS satellite chlorophyll image of highlighting the mesoscale oceanographic structures described by Barton et al. (2004) (C, cyclonic eddy; A, anticyclonic eddy; F, filament; dotted grey line, filaments location). C, location of CTD + LHPR sampling stations. D, schema of the experimental design for the transport simulations (dotted lines, potential release zones; black square, target area). The islands of Tenerife (TF), Gran Canaria (GC) and Fuerteventura (F) are identified in the maps.

and their ecological consequences for the African and Canary metapopulations. In the context of the biogeography of oceanic islands, we highlight the potential role of mesoscale oceanographic structures in the colonization events of not only marine biota but also terrestrial fauna and flora.

\section{MATERIALS AND METHODS}

\section{Field observations}

To investigate the relationship between the eddyfilament system and the distribution of decapod larvae in the C-ACTZ, the sampling stations were selected onboard using daily sea surface temperature (SST) satellite images to ensure that the cruise sampled most of the complex oceanographic scenario (Fig. 1). Following the terminology used in Barton et al. (2004) and Rodríguez et al. (2004) the stations were arranged in one long section, seven short transects and two isolated stations (Fig. 1C). Five of the short transects (S, F, Q, $\mathrm{W}$, and $\mathrm{Y}$ ) crossed the upwelling filaments (F1 and F2) perpendicularly at different distances from the African coast. Transect V cut filament F2 and the anticyclonic eddy A7 located southwest of Fuerteventura, whereas transect $\mathrm{Z}$ crossed the anticyclonic eddy A6 and the warm island wake south-southeast of Gran Canaria (Fig. 1B). The two isolated stations, D2 and D4, corresponded to 24-h time series following surface drifters. In total, 37 stations were sampled from 5 to 27 August 1999 during the FAX99 cruise on board the R/V Hespérides. At every station, conductivity, temperature, depth, and fluorescence casts were made from surface to $200 \mathrm{~m}$ depth with a Neil Brown MKIII CTD to characterize the hydrographic conditions. Decapod larvae samples were collected with a Longhurst-Hardy Plankton Recorder (LHPR) fitted with a 200- $\mu$ m mesh and a calibrated flow meter. The LHPR was towed at 3 to 4 knots on long oblique hauls, sampling from surface to $200 \mathrm{~m}$ depth (or $10 \mathrm{~m}$ above the bottom at 
shallower stations). On the recovery of each sample, the zooplankton was removed from the meshes and was preserved in $4 \%$ borax-buffered formaldehyde prepared using seawater. According to Rodríguez et al. (2006), at every station the individual 2-min strata were aggregated into nine strata corresponding to the following depth ranges: $0-20,20-35,35-50,50-66$, 66-82, 82-100, 100-124, 124-151 and 151-200. At the shallower stations, D2 and LS24, the bottom depth permitted sampling only for 85 and $80 \mathrm{~m}$, respectively.

Once in the laboratory, decapod larvae were sorted and quantified. Larvae were identified using the guides given by dos Santos and Lindley (2001) and dos Santos and González-Gordillo (2004), and using the specific taxonomic descriptions recommended in the checklist of González-Gordillo et al. (2001). General taxonomical nomenclature follows De Grave et al. (2009).

\section{Statistical analysis}

The abundance of larvae collected in each haul was standardized to the number per $100 \mathrm{~m}^{3}$. The species were grouped into two functional groups (pelagic and benthic) according to adult distribution (d'Udekem d'Acoz 1999). Multivariate methods were used to test whether different larval patterns could be detected in relation to mesoscale oceanographic variability. The null hypothesis was that there were no significant differences between larval composition and environmental conditions between three different oceanographic regions defined in Barton et al. (2004) and Rodríguez et al. (2004) (Fig 1B). The first region (upwelling filaments) included stations influenced by the upwelling and filaments (LS23, LS24, V4, V6, D2, F2, S12, $\mathrm{S} 14, \mathrm{~S} 16, \mathrm{~S} 18)$. A second region (eddy) included stations located in eddy areas (LS11, LS12, LS13, LS15, LS17, V10, V8, Z2, Z4, Z7, Z10, Z13, Z15), and the last region (stratified) included oceanic stations with a well-stratified water column (LS19, LS21, F5, F9, Q6, Q8, Q10, W32, W34, W37, Y12, Y9, Y16). We determined whether these regions were well established using a one-way analysis of similarity (ANOSIM) test from the resemblance Euclidean distance matrix of the normalized environmental variables in each station: SST, depth of $18.5^{\circ} \mathrm{C}$ thermocline and sea surface chlorophyll fluorescence (Clarke 1993, Clarke and Warwick 2001). These regions were then used as factors to test larval assemblages. For larval assemblages, a non-metric multidimensional scaling (nMDS) ordination based on the respective Bray-Curtis similarities matrix was displayed, generated from the $\log (\mathrm{x}+1)$ transformed abundance data to reduce the weighting of dominant species (Clarke and Warwick 2001). It is assumed that stress coefficients $<0.15$ indicate a good representation of data (Clarke and Gorley 2006). A one-way ANOSIM test was performed to evaluate larval differences between the three defined regions. The factor included in the ANOSIM analyses was "region" with three levels: upwelling, eddy and stratified. When pairwise comparison in the ANOSIM test detected significant differences between regions, similarity percentage analysis (SIMPER) was used to determine which species were contributing most to differentiate these regions (Clarke and Warwick 2001, Clarke and Gorley 2006). The SIMPER results were illustrated by plotting the mean relative abundance of key taxa by regions using the JColorGrid data visualization program (Joachimiak et al. 2006).

The BIOENV procedure (Clarke and Gorley 2006) was used to determine the set of environmental variables (similarity calculated with the Euclidean distance coefficient) that best explained the larval assemblages. The environmental variables included SST, sea surface salinity, depth of the $18.5^{\circ} \mathrm{C}$ isotherm, minimum distance to the African coast, and sea surface chlorophyll. Prior to the analysis, a draftsman plot (scatter plots between pairs of environmental variables) was used to assess the linearity of the data and the inter-correlation between variables. All multivariate statistical analyses were carried out using the PRIMER v.6 software package (Clarke and Gorley 2006).

\section{Hydrodynamic model configuration}

The Regional Oceanic Modelling System (ROMS; Shchepetkin and McWilliams 2005, 2009) was used to make a one-way nested solution covering the period of the FAX cruise. ROMS has been extensively applied and validated in the eastern boundary upwelling system regions (e.g. Penven et al. 2005, Marchesiello and Estrade 2009, Veitch et al. 2010). Its weakly diffusive advection scheme preserves sharp fronts and maintains realistic levels of eddy kinetic energy (Capet et al. 2008, Colas et al. 2013).

The 7.5-km resolution parent configuration is identical to that of the Canary Basin seasonal study by Mason et al. (2011), bar the use of interannual rather than climatological forcing. The setup is fully mesoscaleresolving. The model was initialized on 1 January 1985 using data from version 2.1.6 of the Simple Ocean Data Assimilation (SODA) global ocean model (Carton and Giese 2008) and was run for 16 years until 2001. Lateral boundary updates from SODA were applied every five days. Monthly mean surface forcing, including wind stress and fluxes of heat and freshwater, was taken from the Climate Forecast System Reanalysis (CFSR; product ds093.2) (Saha et al. 2010). CFSR features a semicoupled oceanic/terrestrial/atmospheric model. Wind stresses were computed from the CFSR $10 \mathrm{~m}$ wind speed components $\left(\sim 0.31^{\circ}\right)$ following Smith (1998). Mild restoring of ROMS SST and salinity is towards the relatively coarse $\left(0.5^{\circ}\right)$ respective monthly CFSR data. A 3-km-resolution nested solution covering the years 1998 to 2000 was obtained using the same grid and downscaling techniques as those described by Mason et al. (2010). The monthly CFSR surface forcings were used for all variables apart from the wind stress, for which six hourly fields from the Cross-Calibrated Multi-Platform (CCMP) observational wind velocity product of Atlas et al. (2011) were used. Daily averages of the output variables were stored for the forcing of the Lagrangian model.

Figure 2 shows mean SST for the month of $\mathrm{Au}-$ gust 1999 from (a) the nested model and (b) satellite 

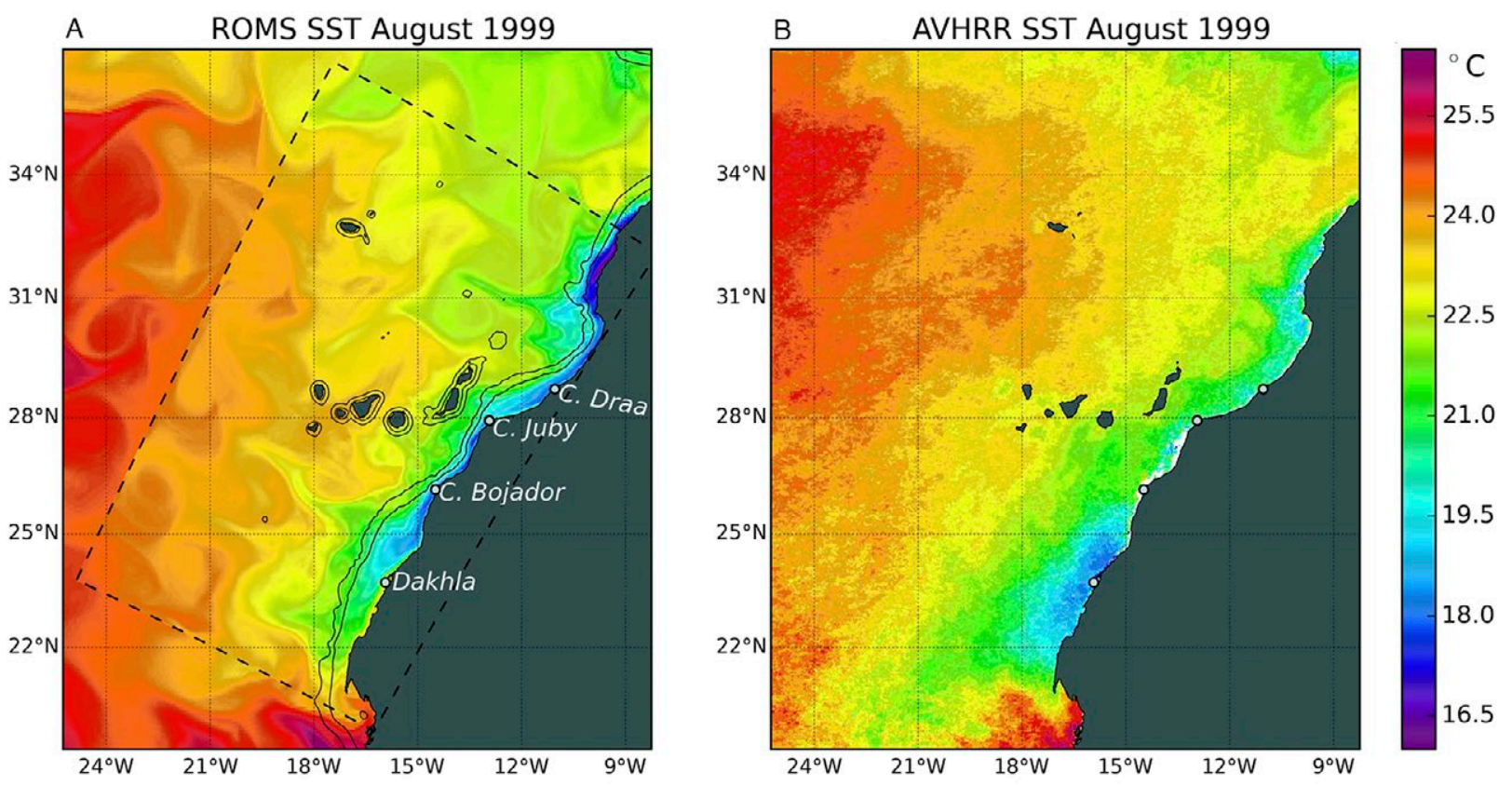

Fig. 2. - Monthly mean SST for August 1999 over the Canary Island region from ROMS (A), and AVHRR V5.2 (B). Dashed lines in A mark the ROMS model domain used for the analysis in Figure 3. Black contours in A correspond to the respective model grid topographies at 200 and $1000 \mathrm{~m}$.

observations (4 km AVHRR Pathfinder V5.2; Casey et al. 2010). To remove the influence of low-quality and cloud-obscured pixels, the AVHRR data, comprising 62 night-time and daytime observations (1/8/1999 through 31/8/1999), with quality levels $\geq 4$, were spatially bin-averaged onto a $0.15^{\circ} \times 0.15^{\circ}$ grid before final calculation of the mean. The model mean SST shows generally good agreement with the resulting satellite SST. There is a strong cross-shore SST gradient, where the lowest SST at the coast is associated with the upwelling. The highest SSTs are found in the northwest of the domain, and also at the coast in the south of the domain. Discrepancies include generally lower SSTs at the coast in the model; the model upwelling SST intensifies north of Dakhla, whereas in the observations it is more intense to the south. The finding of a model nearshore cool bias may be a consequence of a known Canary upwelling warm bias in the AVHRR 5.2 product (Dufois et al. 2012). The model shows clear signals of filament activity at Cape Ghir and between Cape Bojador and Dakhla. There is a notable match with the satellite SST at Cape Ghir, both model and observations suggesting a double filament, the main filament at the latitude of Cape Ghir and a smaller secondary filament just to the south. Cyclonic circulation associated with this SST pattern is in agreement with climatological model and satellite sea level anomaly observations of genesis of Rossby waves near Cape Ghir in summer (Mason et al. 2011). In the study area south of the Canary Islands it is less easy to discern evidence of filament activity in the monthly mean satellite SST.

Figure $2 \mathrm{~A}$ also demonstrates the success of the nesting procedure between the outer $7.5 \mathrm{~km}$ and inner $3 \mathrm{~km}$ solutions. In most instances there is agreement between mesoscale features along the boundaries.
However, along the western boundary the $3 \mathrm{~km} \mathrm{SST}$ is $\sim 0.5^{\circ} \mathrm{C}$ lower than the $7.5 \mathrm{~km} \mathrm{SST}$; this may be a consequence of the use of the high frequency CCMP wind forcing for the inner solution (e.g. Mason et al. 2010). Although we used high frequency wind forcing, the timing of the simulated mesoscale variability, i.e. coastal filaments and their interactions with topographic eddies downstream of the islands, cannot be expected to match the observed variability because of the stochastic nature of the associated processes.

In Figure 3 we show two maps of daily SST from a few days before and a few days after the cruise, and compare them with contemporaneous snapshots of observed SST (AVHRR Pathfinder V5.2, $4 \mathrm{~km}$ ). From the first pair of SST snapshots (top row) at the beginning of August and the second pair (bottom row) at the end of August, it can be seen that the model captures the synoptic patterns and variability. The AVHRR image on 3 August shows clear evidence of a cold filament (F1, also Fig. 1B) extending from the coast south of Cape Juby to Gran Canaria. The corresponding model SST also shows a cold filament reaching the vicinity of Gran Canaria, but its origin is nearer to Cape Bojador to the south. Both the observed and simulated filaments turn to the south, setting up a cyclonic circulation (C7, Fig. 1B). The second pair of SST snapshots at the end of August show a general warming in comparison with early August. Mesoscale patterns are weaker (possibly obscured through surface heating) and less extensive. In the model a looping cold filament reaches Gran Canaria from the south; by contrast, the satellite SST shows a frequently-observed warm wake anomaly downstream of Gran Canaria (Barton et al. 2000).

For a global view of the fidelity of the model, Figure 3 also includes time series of SST for all of 1999 

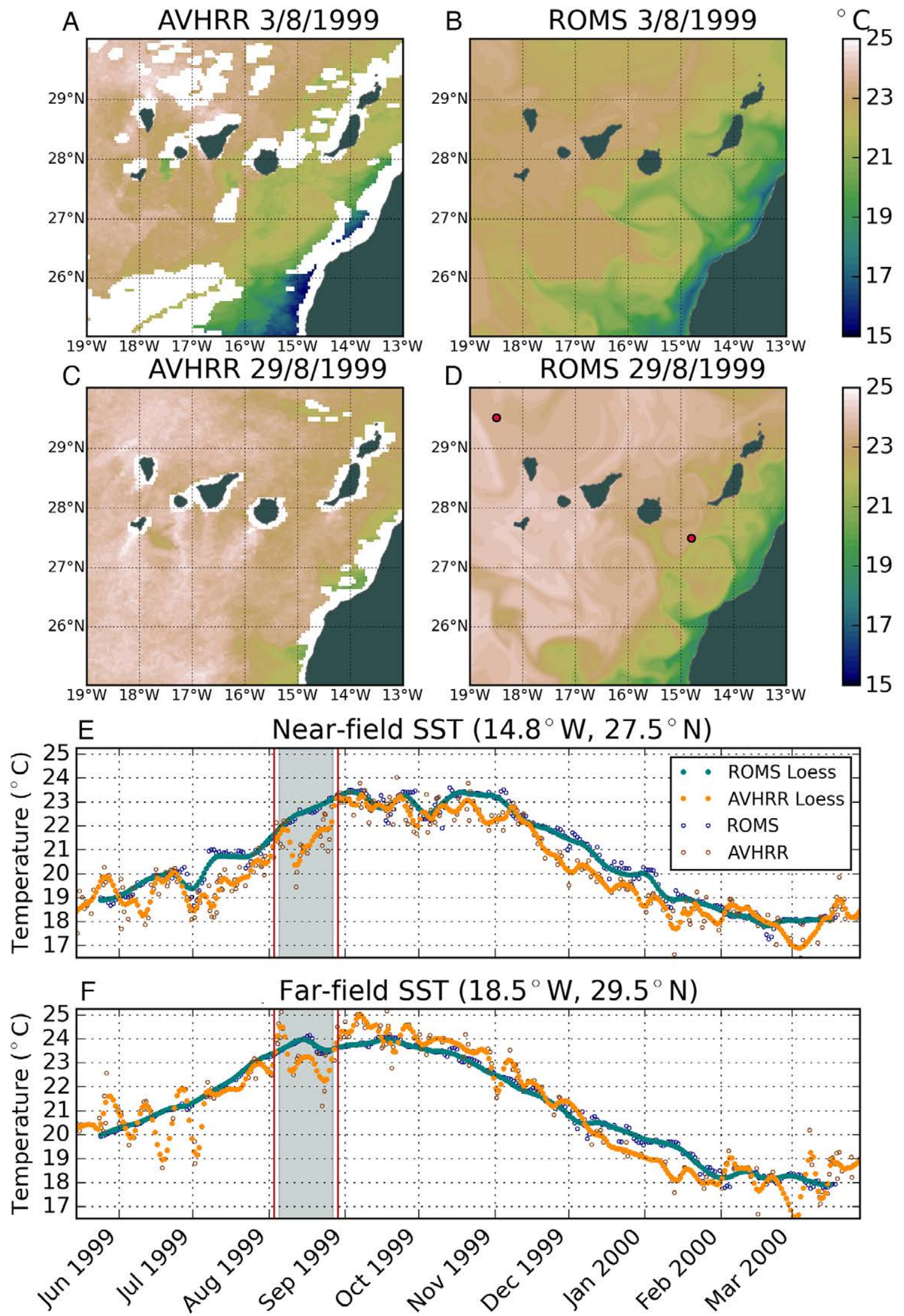

Fig. 3. - Snapshots of observed (AVHRR, $4 \mathrm{~km}$ ) and simulated SST at the beginning (A, B) and end (C, D) of August 1999, showing that the model produces strong mesoscale activity associated with the coastal upwelling. Red points in D mark the positions of near- and far-field stations for the time series in E, F. E, time series of smoothed and raw AVHRR and ROMS SST at a near field station inside the FAX study area. F, same as E but at a far-field station well outside the coastal upwelling. Red vertical lines mark the respective dates of the snapshots in A-D. The thick grey bar marks the period of the FAX cruise (4-27 August). 
from ROMS and AVHRR at two different locations: (i) a near-field station located in the study area within the upwelling (Fig. 3E); and (ii) a far-field station located to the northwest of the Canary Islands, well outside the upwelling (Fig. 3F). The AVHRR data were prepared similarly to those in Figure 2, but with one extra step. In order to remove any remaining gaps after quality filtering and spatial bin averaging, a lowpass 1-dimensional Loess smoother with a half-power cutoff of 30 days was applied to the time series of 2029 images (13/12/1997 through 11/10/2000). For consistency, the daily model data were also bin-averaged and Loess smoothed.

Loess-smoothed AVHRR and model SST values in Figure 3E for the period June 1999 to March 2000 at the near field station are generally coherent. Differences between the sample means are $<4 \%$ (Table 1 ). The AVHRR data show considerably more variability on scales of a few days to weeks. In both early summer and late autumn to winter, the model data show a small warm bias of $\sim 1^{\circ} \mathrm{C}$. During the FAX cruise in August, this bias increases to $>2^{\circ} \mathrm{C}$ as a result of a month-long period of sustained cooling at the surface that is not captured by the model (the unsmoothed AVHRR data shown in Figure $3 \mathrm{E}$ drop to below $19.5^{\circ} \mathrm{C}$ on $12 \mathrm{Au}-$ gust). A possible explanation for this difference over the cruise period is the restoring of ROMS SST towards coarse $\left(0.5^{\circ}\right)$ monthly mean SST from CFSR. At the far-field station in Figure 3F, the fit between the two smoothed time series is improved, and variability is greater (Table 1). Interestingly, during the period of the cruise, a cooling pattern that is apparently coincident with the cooling at the near-field station is seen in both the satellite and model data. Cooling of the model SST begins just after 15 August, suggesting that it is mediated by restoring towards cool local September CFSR SST.

\section{Transport model and simulations}

The hydrodynamic simulations were used to force Ichthyop (Lett et al. 2008), a Lagrangian transport model that allows the evaluation of the vertical behaviour on larval transport and backtracking. The virtual larvae performed diel vertical migration (DVM) between the surface and $60 \mathrm{~m}$ depth and were passively advected by the 3-D model current. In the mean (calculated for the period 23/7/1999 to 21/9/1999), the horizontal currents between the surface and $\sim 60 \mathrm{~m}$ in the lee of Gran Canaria were cyclonic. Along the African coast, a surface-intensified upwelling jet was accompanied by positive vertical velocity $(w)$ values exceeding $5 \mathrm{~m}$ day $^{-1}$. At the particle release area just south of Gran Canaria, mean $w$ of $\sim 2 \mathrm{~m} \mathrm{day}^{-1}$ were directed downward. Transient values of $w$ were higher than these mean values, and were associated with evolving mesoscale fronts and filaments. For context, the flow associated with the different features during the FAX99 study was largely barotropic over the assumed larval vertical migration range of $60 \mathrm{~m}$, although within the filament structures some weak shear $\left(<310^{-3} \mathrm{~s}^{-1}\right)$ was present. The origin of the larvae found in the sampling
Table 1. - SST $\left({ }^{\circ} \mathrm{C}\right)$ sample means and variances (in parenthesis) for the Loess-smoothed AVHRR and ROMS SST time series at the near- and far-field stations shown in Figure 3. See Figure 3D for the locations of the two stations.

\begin{tabular}{lcc}
\hline & AVHRR Loess & ROMS Loess \\
\hline Near-field & $20.23(3.35)$ & $20.78(3.42)$ \\
Far-field & $21.15(5.11)$ & $21.27(3.96)$ \\
\hline
\end{tabular}

area was investigated using a backward Euler scheme (implemented in Ichthyop), which allows the backtracking of the individuals passively transported by the currents. The sampling area considered was a square of $\sim 25 \mathrm{~km}^{2}$ south of Gran Canaria, at $27^{\circ} 19^{\prime} \mathrm{N}-27^{\circ} 35^{\prime} \mathrm{N}$ and $15^{\circ} 17^{\prime} \mathrm{W}-15^{\circ} 33^{\prime} \mathrm{W}$ (black polygon, Fig. 1D). We selected this area because, there, we observed both early and late larval stages of neritic species that may suggest larval mixing (different population sources of larvae in the Canary Islands and in the African coast).

To elucidate transport pathways, 10000 particles (virtual larvae) were randomly distributed in the sampling area south of Gran Canaria each day of August 1999 and were backtracked for 15 days (as an estimated minimum planktonic larval duration in decapods). Each backtracked trajectory was analysed by an algorithm which determined whether the trajectory crossed one of the following areas inshore of the $1000 \mathrm{~m}$ isobaths: (1) the African coast, and around (2) Gran Canaria, (3) Fuerteventura and (4) Tenerife (Fig. 1D). For each backtracking experiment on a given date, this analysis provided a distribution of the relative contribution of these areas to the larvae found in the sampling area. The variability of particle sources in the sampling area, driven by the strong mesoscale activity in the C-ACTZ, was studied by looking at the temporal evolution of the relative contribution of each defined area to the larvae found in the sampling area.

\section{RESULTS}

\section{Oceanographic conditions}

The hydrography of the study area during the cruise has been described in detail by Barton et al. (2004). The cruise coincided with an upwelling-favourable period, although winds were weaker $\left(<15 \mathrm{~m} \mathrm{~s}^{-1}\right)$ than in other studies in the same season (Barton et al. 1998, 2000, Basterretxea et al. 2002). During the cruise, cool and productive waters near the African coast contrasted with the warmer and oligotrophic waters in the open ocean. The AVHRR SST images (Fig. 2) revealed the typical mesoscale structures present in the C-ACTZ area (filaments and several cyclonic and anticyclonic eddies), denoting a highly complex oceanographic scenario. According to Barton et al. (2004), in early August (see schema in Fig. 1B), a single filament extended offshore from Cape Bojador (F2). Two weeks later, a second filament (F1) developed near Cape Juby, interacted with the anticyclone A7 south of Fuerteventura, and extended offshore to merge with F2 at $100 \mathrm{~km}$ offshore. The merged filament was entrained around a recurrent, topographically trapped cyclonic eddy (C7) between the Canary Islands and the Afri- 

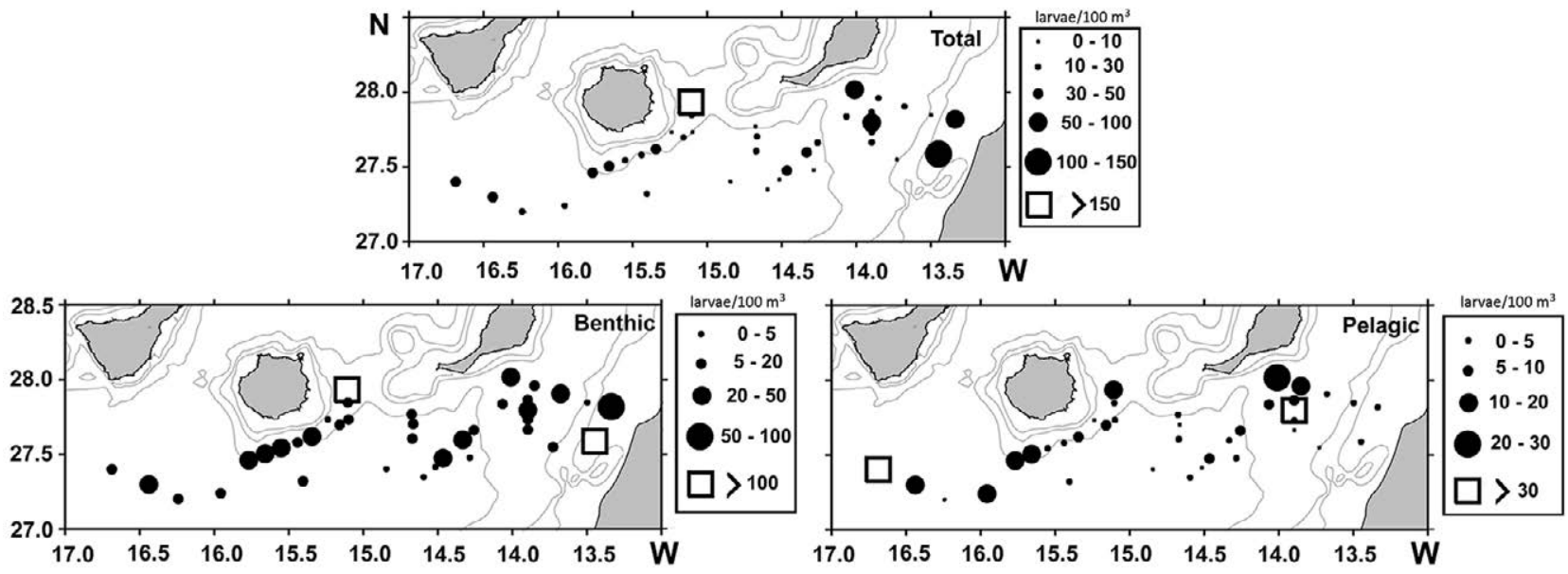

Fig. 4. - Horizontal distribution of total decapod larvae abundances and larvae of benthic and pelagic species. Symbol size and shape represents densities (larvae/100 $\mathrm{m}^{3}$ ), as indicated in the scale.
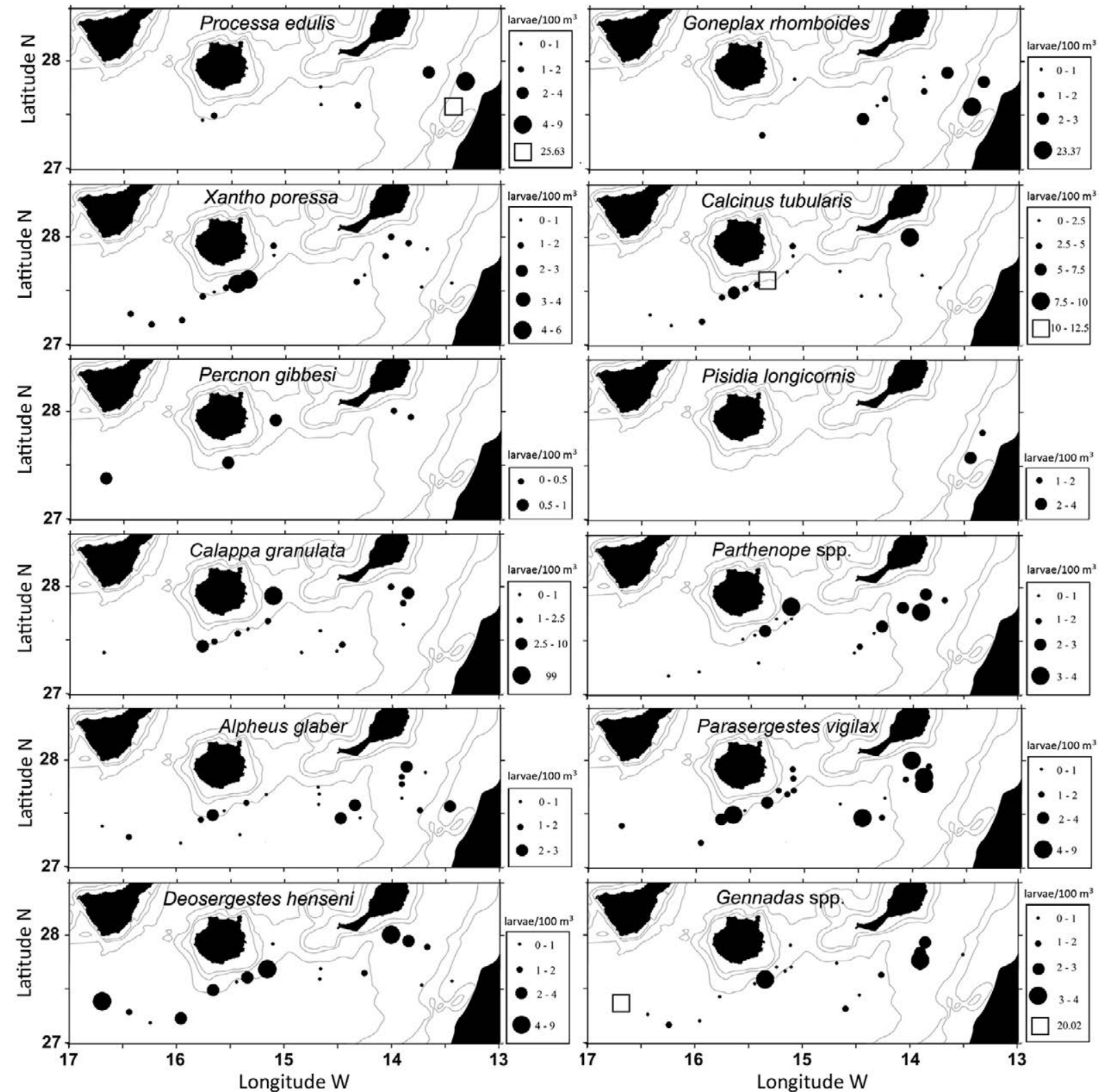

Fig. 5. - Horizontal distribution of decapod larvae abundances. Symbol size and shape represents abundance (larvae/100 $\mathrm{m}^{3}$ ), as indicated in the scale. 
can coast, and interacted with transient cyclonic and anticyclonic eddies shed from the islands of Tenerife (A1) and Gran Canaria (A6). The oceanographic conditions were significantly different between upwelling filaments (UF), eddies (E), and stratified (S) regions (ANOSIM $\mathrm{R}=0.48, \mathrm{P}=0.001$ ), in agreement with the station delimitation defined in Barton et al. (2004) and Rodríguez et al. (2004).

Field observations of decapod larvae: composition, distribution and assemblages

A total of 2397 larvae were caught, comprising 110 identifiable taxa (Table $\mathrm{S} 1$ in Supplementary material). In general, low larval densities and large variability were observed among stations, with a mean value of $32.3 \pm 30.7$ larvae $/ 100 \mathrm{~m}^{3} \pm \mathrm{SD}$. It was also noteworthy that benthic species ( $74.1 \%$ of total larvae) were more abundant than pelagic ones $(25.9 \%)$. The most abundant taxa were Calappa granulata $(10.5 \%)$ and Callianassidae SL16 (7.9\%), followed by Processa edulis crassipes (3.4\%), Goneplax rhomboides (3.0\%), Xantho poressa (2.4\%) and Alpheus glaber (2.3\%). On the other hand, pelagic Sergestidae were the most diverse family, mainly represented by Parasergestes vigilax (4.6\%) and Deosergestes henseni (3.3\%) (Table S1 in Supplementary material).

Significant spatial variability of decapod larvae was associated with mesoscale oceanographic structures. The average abundances were rather similar among upwelling, eddy and stratified regions (Table S1 in Supplementary material). The horizontal distribution map of total abundance showed higher densities at stations LS24, D2, Y12 and V10, but no clear spatial trends were observed (Fig. 4). However, when pelagic and benthic abundances were analysed separately, two distinct distribution patterns were detected (Fig. 4). The pelagic larvae were more closely related to the eddies $\left(14.3 \pm 12.0\right.$ larvae/100 $\left.\mathrm{m}^{3}\right)$, while the lowest densities occurred in upwelling $\left(7.3 \pm 11.5\right.$ larvae $\left./ 100 \mathrm{~m}^{3}\right)$ and stratified regions $\left(4.30 \pm 4.6\right.$ larvae $\left./ 100 \mathrm{~m}^{3}\right)$ (Table $\mathrm{S} 1$, Fig. 4).

This eddy association was also evident in distribution maps of Parasergestes vigilax, Deosergestes henseni and Gennadas spp. (Fig. 5). In contrast, the benthic species were more homogeneously distributed, but with the highest abundance in the upwellinginfluenced stations $\left(30.5 \pm 35.1\right.$ larvae $\left./ 100 \mathrm{~m}^{3}\right)$ and the lowest abundances in eddies $\left(23.0 \pm 13.1\right.$ larvae $\left./ 100 \mathrm{~m}^{3}\right)$ and stratified areas $\left(20.3 \pm 34.6\right.$ larvae/100 $\left.\mathrm{m}^{3}\right)$ (Table S1, Fig. 5). Differences in spatial patterns were also evident in some representative benthic species (Figs 5 and 6).

The horizontal distribution of Processa edulis, Goneplax rhomboides (Fig. 5), and Callianassidae SL16 (Fig. 6) were influenced by the African upwelling and associated filaments. These species showed the highest densities over the African shelf but were apparently advected offshore, reaching eddies $\mathrm{C} 2$ and A1, south of Gran Canaria. This was clearly seen in the distribution of Callianasidae SL16 in different stages of its development, because as the larvae aged they were found

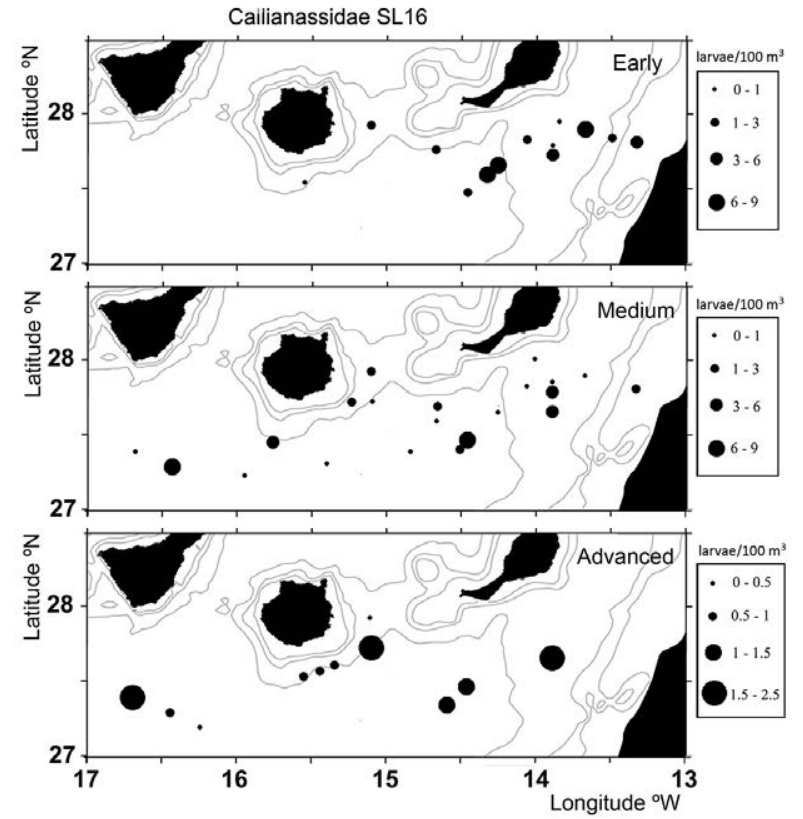

Fig. 6. - Horizontal distribution of the abundance of the Callianassidae SL16 larvae in early, medium and advanced stage of development. Symbol size represents densities (larvae/100 $\mathrm{m}^{3}$ ), as indicated in the scale.

further from their spawning grounds in the nearshore upwelling area (Fig. 6).

However, there were other larval distributions suggesting both the Canary Islands and the African coast as locations of larval origin. This is the case for Xantho poressa, Alpheus glaber and Calcinus tubularis, which were found in their first stage of development (zoea I) at stations Y12 and Z14, close to Gran Canaria, and at stations LS23 and LS24, influenced by the upwelling (Fig. 5). The horizontal distribution pattern of Percnon gibbesi larvae was quite different from that of other benthic species, suggesting a single origin in the $\mathrm{Ca}$ nary Islands (Fig. 5). This species was absent from the upwelling area but present as zoea I stage south of Fuerteventura and Gran Canaria at stations V10 and Z10, respectively. Other neritic species such as Pisidia longicornis (Fig. 5), Palaemon elegans and P. serratus were collected only at LS24 and D2 on the African shelf, suggesting that they were not influenced by filament or eddy motions.

Larval assemblages differed among the defined regions $U F, E$, and $S$ (ANOSIM $R=0.35, P=0.002$ ). The pairwise comparison tests detected that region $\mathrm{E}$ was also rather different in larval composition and abundance from $\mathrm{S}$ (ANOSIM R=0.41, $\mathrm{P}=0.001$ ) and UF (ANOSIM $\mathrm{R}=0.23, \mathrm{P}=0.001$ ). However, larval assemblages in UF and $\mathrm{S}$ were not significantly different (ANOSIM $\mathrm{R}=0.02, \mathrm{P}=0.32$ ). The non-metric multidimensional scaling (nMDS) ordination revealed some spatial structure in the larval assemblage (stress coefficient 0.11, Fig. 7A). The spatial distribution of these assemblages (Fig. 7B and C) shows that the stations more influenced by the upwelling and the filaments (LS24, D2, V4, V6) and the stations located near islands (Z13, Y9, Y12, V10), characterized by 


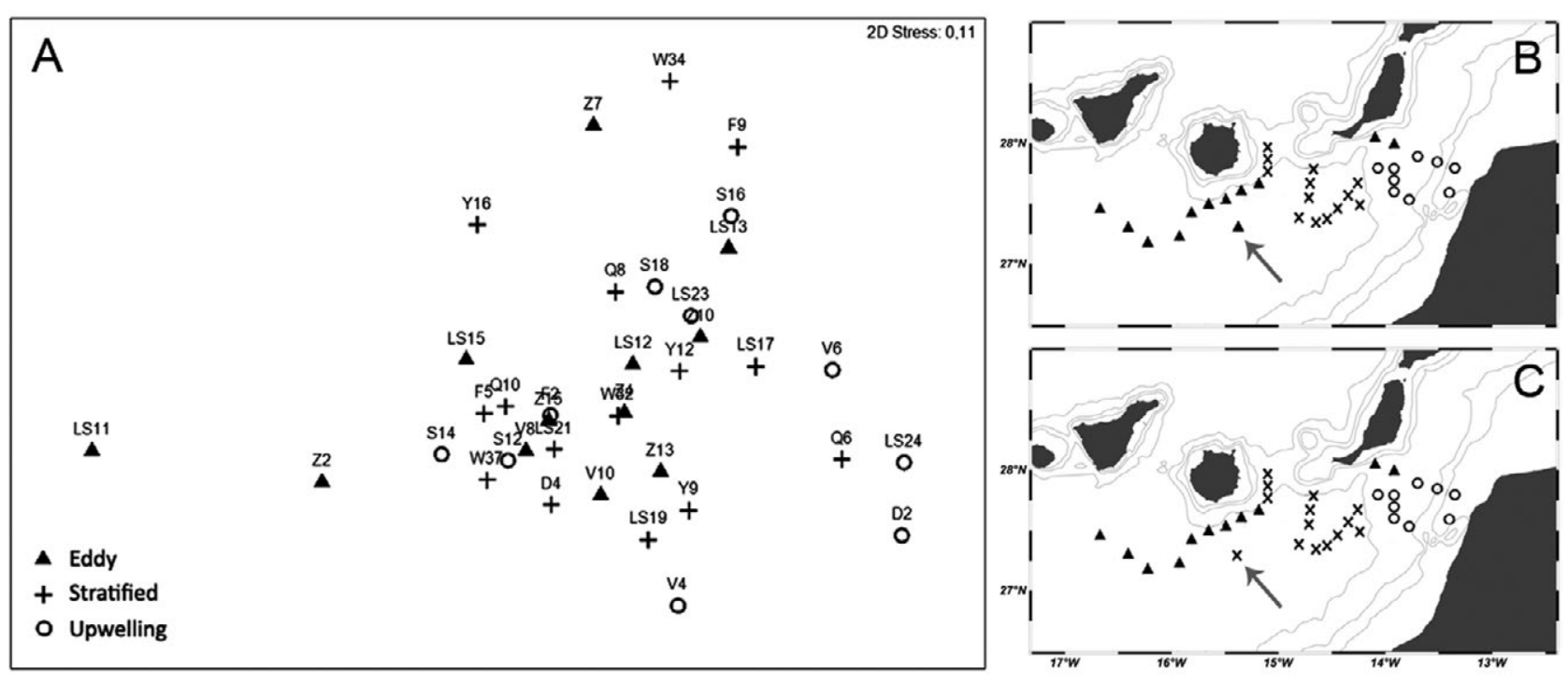

Fig. 7. - Non-metric multidimensional scaling (nMDS) plot showing sample assemblages based on a Bray-Curtis similarity matrix of the larval abundances of decapods (A). Spatial distribution of the environmental (B) and decapod larvae assemblages (C) in the C-ACTZ. Grey arrow highlights the only station without assemblage matching.

higher densities of neritic species, were grouped together. In contrast, the stations located near eddies and/or far from Africa coast (LS11, Z2, LS15) were also grouped on the opposite side of the plot. SIMPER analysis, applied to decapod larvae abundance data (Table 2), detected which species contributed the most to the differences between region $\mathrm{E}$ and the others, UF and $\mathrm{S}$.

Equally notable in our survey was the absence (or rarity) of larvae from taxa that are common in our sampling region as adults. The pelagic species $D e$ osergestes henseni, Parasergestes vigilax, Sergestidae spp. and Gennadas spp., whose distributions were closely related to region $\mathrm{E}$ and were almost excluded from regions UF and S, achieved around 25\% average dissimilarities (Table 2). Calcinus tubularis and Xantho poressa (more abundant in region $\mathrm{E}$ due to their Canaries origin) also helped distinguish the group E from groups UF and S. Finally, the filament-associated species Callianassidae SL16, Processa edulis and Goneplax rhomboides achieved an important percentage of dissimilarities between regions (Table 2).
The BIOENV test demonstrated that decapod larva assemblages were significantly correlated with environmental patterns $(\mathrm{P}=0.005)$, but the degree of correlation was relatively low $(\mathrm{P}=0.371)$. The spatial distribution of both larval and environmental assemblages is shown in Figure 7A, B, where station LS17 (highlighted in the maps with an arrow) is the only one that does not match. The BIOENV analysis revealed that "minimum distance to Africa coast" was the most important single variable, with $70.3 \%$ of explained larval variability. The best pair combination was for "minimum distance to Africa coast" and "SST", which explained $89.6 \%$ of total variability in decapod larvae distributions.

In general, the key species followed a similar pattern of vertical distribution. Most larvae displayed a distinct variation with depth, although the species Goneplax rhomboides and Gennadas spp. showed the least stratified vertical distribution (Fig. 8). Of the larvae, $81.3 \%$ to $89.1 \%$ were concentrated between 0 and 66 $\mathrm{m}$ depth, and they were observed in very low densities in the deepest strata (124-200 m) (Fig. 8). Total larvae

Table 2. - Pairwise comparisons of decapod larva assemblages between the regions: E, eddy; S, stratified; UF, upwelling filaments (see the "statistical analysis" section for details). Values correspond to the percentage of dissimilarity (SIMPER analysis) of the species that contributed to $70 \%$ average dissimilarity. In bold, the three species that mostly contribute to the differences among regions. Grey scale corresponds to changes in mean relative abundance $\left(\log \left(\operatorname{larvae} / 100 \mathrm{~m}^{3}+1\right)\right)$ in each region.

\begin{tabular}{|c|c|c|c|c|c|c|}
\hline & E & $\mathrm{S}$ & UF & Eddy $v s$ Upwelling & Eddy $v s$ Stratified & \\
\hline Parasergestes vigilax & & & & 5.68 & 6.13 & \multirow{13}{*}{0.5} \\
\hline Deosergestes henseni & & & & 6.18 & 7.94 & \\
\hline Sergestidae spp. & & & & 5.51 & 5.66 & \\
\hline Gennadas spp. & & & & 4.33 & 6.11 & \\
\hline Callianassidae SL16 & & & & 6.22 & 6.54 & \\
\hline Calcinus tubularis & & & & 7.38 & 9.24 & \\
\hline Processa edulis crassipes & & & & 5.48 & - & \\
\hline Goneplax rhomboides & & & & 5.35 & - & \\
\hline Xantho poressa & & & & 5.36 & 6.95 & \\
\hline Calappa granulata & & & & 4.30 & 6.56 & \\
\hline Parthenope spp. & & & & - & 4.59 & \\
\hline Parthenopidae spp. & & & & 3.71 & 4.71 & \\
\hline Average dissimilarity & & & & 75.57 & 70.81 & \\
\hline
\end{tabular}



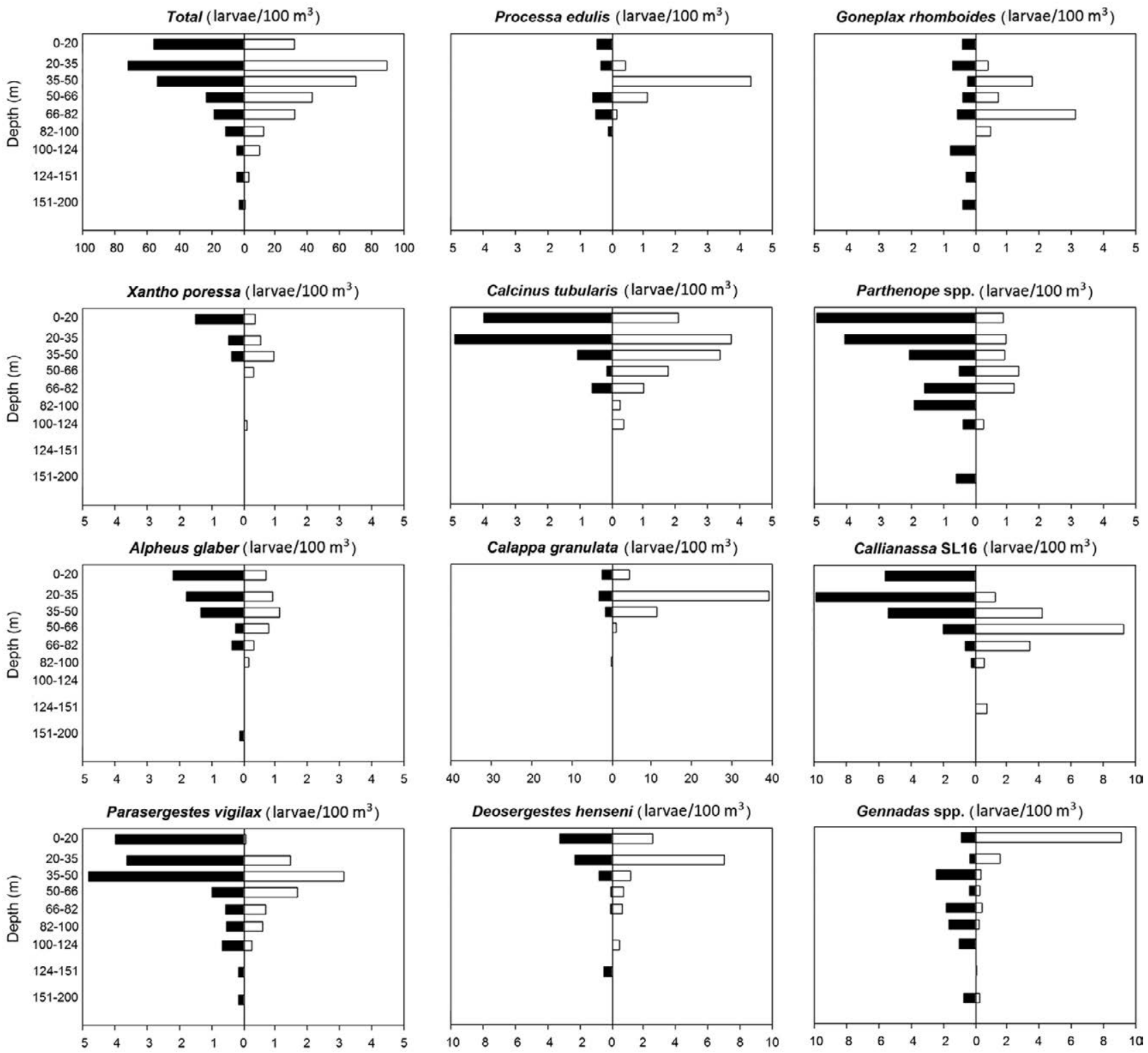

Fig. 8. - Mean day (open bars)/ night (filled bars) vertical distribution of decapod larvae (larvae/100 $\mathrm{m}^{3}$ ).
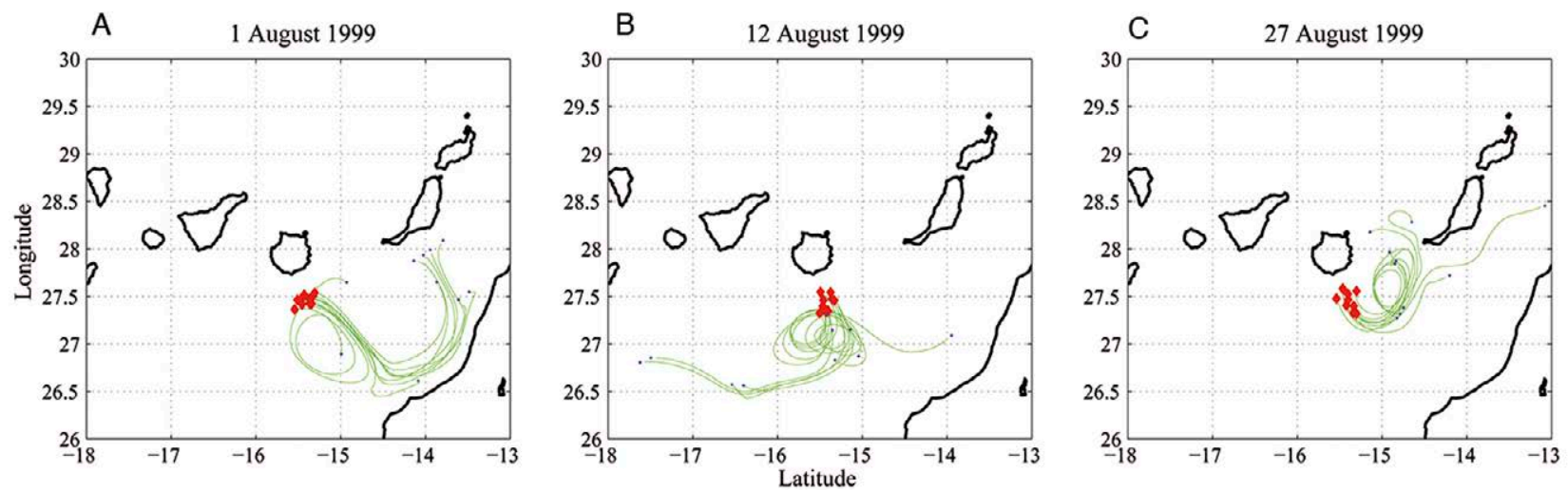

Fig. 9. - Example of backtracking trajectories of larvae sampled area south of Gran Canaria (red dots) on 1 August (A), 12 August (B) and 27 August 1999 (C). The green lines show the simulated pathways followed by the larvae during the 15 days before they reach the sampling area (red dots) according to the hydrodynamical model. 


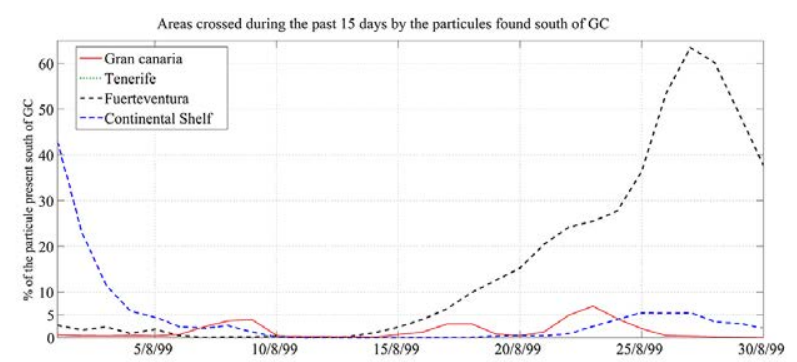

Fig. 10. - Contribution of Gran Canaria, Tenerife, Fuerteventura islands coastal area and the African continental shelf to the particles sampled south of Gran Canaria. Note that the Tenerife contribution was null.

and most of the selected taxa followed almost identical patterns of vertical distribution during day and night. Only the larvae of Callianassidae SL16 and Parasergestes vigilax exhibited DVM, moving towards the surface during the night.

\section{Backward transport simulations}

Figure 9 shows examples of backtracking of particles sampled in a square offshore of the south of Gran Canaria (GC) on three different dates, illustrating the different oceanic source areas from which particles may reach the south of GC within two weeks. The repetition of these simulations each day of August 1999 (Fig. 10) showed that at the beginning of the month up to $40 \%$ of the virtual larvae in the sampling area originated from the African continental shelf, mainly from the area between Cape Bojador and Cape Juby (Fig. 9). This African contribution declined rapidly, so between 5 and 10 August, the continental shelf contributed $<5 \%$, equal to the contribution from the much closer coastal area around GC. Between 10 and 14 August, no particles sampled south of GC crossed mainland or island continental shelves. This period is marked by a contribution from areas farther south of GC and southwest of Tenerife (Fig. 10). During the second half of the month, the contribution from the Fuerteventura coastal area gradually increased to peak on 27 August at $65 \%$ of the particles sampled south of GC. No significant differences in transport patterns were observed between the simulations with DVM and non-DVM of virtual larvae $(<1 \%$ changes of the respective contributions).

\section{DISCUSSION}

This study quantifies the differences in abundance and distribution of decapod larvae between upwellingfilament, eddy and stratified oceanic regions in the C-ACTZ, where the larval assemblages and transport pathways are poorly known. The waters downstream of the Canary Islands showed intense mesoscale activity during the FAX99 cruise. SST images revealed the presence of 14 cyclonic and anticyclonic eddies as well as 4 UF (Barton et al. 2004). Our field observation and transport modelling illustrate a close relationship between these mesoscale oceanographic structures and the distribution of decapod larvae. In general, we observed that different transport patterns occur in the study area and that the transport strength varies among taxa and benthic/pelagic adult habitat.

\section{Larvae of pelagic species}

Pelagic larvae were concentrated in the eddy areas and almost absent from the filaments and upwellinginfluenced regions. This marked pattern allowed us to differentiate between the larval assemblages in the C-ATZ, separating the eddy region from the others. The coupling between pelagic species larvae and eddy structures was also observed by Landeira et al. (2009), who reported the highest densities of pelagic species in a cyclonic eddy southwest of GC, where significant larval abundances of pelagic species were also found during the FAX99 cruise. This pattern can be explained by the association of the adult distributions (and consequently their spawning location) with eddy position, as observed by acoustic and net sampling over the deep scattering layer of the Canary Islands waters. In this regard, Foxton (1970a, b) studied a well-developed mesopelagic shrimp community south of Fuerteventura, where we found significant larval densities of Lucifer typus and Deosergestes henseni within the eddy region. Additionally, Bordes et al. (1999) related the increase of mesopelagic shrimps in oceanic waters with the presence of an eddy south of GC and Tenerife, near the eddies A1, C2 and A6, where the larvae of Gennadas spp. and $D$. henseni were more abundant. Rodríguez et al. (1999, 2004) observed similar distribution patterns for pelagic fish larvae of the families Gonostomatidae and Myctophidae, supporting the idea that oceanic eddies may contribute to the maintenance of the pelagic communities, especially in oligotrophic waters off the Canary Islands.

\section{The African continent as a larval source}

Although most of the cruise was conducted in oceanic waters of the C-ACTZ and the densities were relatively low, the greater larval abundance of benthic species compared with pelagic ones indicated the importance of advective processes that transport larvae towards the open ocean. The results suggest two major sources of larvae of benthic species related to specific oceanographic processes: the African coast and the Canary Islands.

The advection of decapod larvae from the African populations was mediated by UF and varied in strength and direction depending on its interaction with oceanic eddies downstream of the islands. This was the case of Processa edulis, Goneplax rhomboides, Callianassidae SL16, C. tubularis and X. poressa, whose distribution patterns were associated with the filament position (Fig. 5). Similar variability was observed in the transport simulations during the first period of the cruise (Fig. 9). In the present study, satellite and field data illustrated two independent filaments stemming from the coast, close to C. Bojador (F1) and C. Juby $(\mathrm{F} 2)$, which merge into a single structure at a distance of around $100 \mathrm{~km}$ offshore. Filament F1 is a quasi- 
permanent structure that develops when the offshore boundary of the coastal upwelling interacts with the permanent cyclonic eddy. Further, the second filament, F2, located around C. Juby, is less permanent because it depends on interaction with the intermittent eddy spun off from the lee of Fuerteventura. The dipole eddy, located between F1 and F2, re-circulates advected water back to the coast (Barton et al. 2004). This situation has suggested that a fraction of the larvae entrained in the filament system could return to their natal populations (Rodríguez et al. 1999, 2004), a finding which is supported by previous hydrodynamic studies in the same area (Brochier et al. 2011). In our case, it can explain why, when these eddies were present in the hydrodynamic simulation, there was no contribution of the coastal areas (either island or continental) to the particles sampled south of GC, confirming the retention role of these mesoscale structures (Fig. 9). Further, in a previous survey conducted during August 1993 in the C-ACTZ, a single filament originating from Cape Bojador also depicted a similar re-circulation (Barton et al. 1998), returning back to Africa most of the neritic fish larvae previously displaced offshore (Rodríguez et al. 1999). In a more recent analysis of samples from the same 1993 cruise, Landeira et al. (2012) found that the larvae of the mud shrimp Upogebia pusilla also depicted a similar transport pattern to that described by Rodríguez et al. (1999). Moreover, nearshore studies in the California (Wing et al. 1998, Mace and Morgan 2006) and Humboldt (Navarrete et al. 2005, Palma et al. 2006) eastern boundary ecosystems demonstrated that eddies formed in the lee of headlands can maintain larvae nearshore in high abundances during strong upwelling periods, favouring recruitment hotspots.

As stated above, not all larvae seemed able to return to the African coast. A fraction of the merged filament $(\mathrm{F} 1+\mathrm{F} 2)$ was extended westward as it interacted with eddies generated south of GC (Fig. 1B). This helps to explain the long distance $(\sim 250 \mathrm{~km})$ travelled offshore by Callianassidae SL16 larvae (Fig. 6). As the larvae were displaced further offshore through the eddyfilament system, they were growing and moulting, reaching as far as the south of Tenerife Island (stations LS11, LS12) in an advanced stage of development.

Satellite images have revealed that eddies detached from the eastern islands of the Archipelago occasionally interact with the offshore boundary of the filaments, dragging upwelled water and extending their transport effect much further westward (Hernández-Guerra et al. 1993, Arístegui et al. 1997). In fact, there was clear evidence of this situation on our cruise. Rodríguez et al. (2004) found strong advection of coastal fish larvae through these oceanographic structures and suggested that the larvae could reach the islands and recruit there. UF are characterized by elevated concentrations of phytoplankton (Barton et al. 1998, Baltar et al. 2009) and mesozooplankton (Rodríguez et al. 2004, Hernández-León et al. 2002a, Yebra et al. 2004) that can enable higher survival rates of decapod larvae during their transport within the filaments (Anger 2001). Recently, intensive monitoring programmes conducted on the island shelf of GC have confirmed the relation- ship between UF and the presence of African larvae in the planktonic insular community (Bécognée et al. 2006, Moyano et al. 2009). Specifically, these works observed that Sardina pilchardus and Engraulis encrasicolus larvae, considered good tracers for UF in the C-ACTZ area (Rodríguez et al. 1999, 2004), were collected only during specific short periods, always coinciding with the arrival of filaments to the islands. Bécognée et al. (2009) observed that fish larvae advected seaward from Africa can be trapped within stationary cyclonic eddies, thus remaining in the oceanic domain. They supposed that the absence of transport to suitable areas for settlement would allow strong predation pressure by mesopelagic diel vertical migrants (Hopkins and Gartner 1992, Hernández-León et al. 2001b, $2002 \mathrm{~b}$ ), leading to a progressive decline and disappearance of the larvae. Hence, it seems logical to think that most of the decapod larvae remaining in the ocean will be lost by predation.

\section{The Canary Islands as a larval source}

On the other hand, larvae originating in the Canary Island populations were mainly located in the area of eddy influence. These larvae were likely advected away from parent populations of the islands by the tides and the general flow of the Canary Current and then trapped by eddies. Some of these larvae could be carried back towards the island by internal wave activity (Sangrà et al. 2001) when they regress shoreward in the eddy circulation (Landeira et al. 2009). In addition, the increase of phyto and zooplankton biomass due to eddy rotation (Hernández-León et al. 2001a, Lasternas et al. 2013) can also favour larval growth and survival (Queiroga and Blanton 2005), because of the greater amounts of food available compared with the surrounding oligotrophic oceanic areas (Barton et al. 1998). Previous studies have already pointed out that eddies can enhance retention near islands (Lobel and Robinson 1988, Rodríguez et al. 2001, Torres et al. 2014). Three representative species of this drifting pathway are Percnon gibbesi, Calcinus tubularis and Xantho poressa. Their origin in the Canary Islands is supported not only by the observation that they are common species of this archipelago (d'Udekem d'Acoz 1999), but also by their horizontal distributions. The absence of $P$. gibbesi larvae at the African shelf stations and in the filament-influenced area (Fig. 5), as well as the presence of the early stage larvae (zoea I) far from Africa, makes the Canary Islands the most probable origin. It is also in accordance with the transport simulation, since the virtual larvae present south of GC originated near Fuerteventura and GC during the second half of the cruise. The same pattern was also observed in two other neritic species ( $C$. tubularis and X. poressa), but in this case the presence of zoea I larvae distant from Canary Islands, in the upwelling-influenced area (LS24 and LS23 stations), suggests one more larval source in the African populations.

The C-ACTZ is a highly complex area, where Canaries and African larvae can cohabit in the same time and space. Our results highlight a strong associa- 
tion between oceanographic mesoscale structures and decapod larvae dynamics. The larvae of pelagic species concentrate their distribution in oceanic eddies. The UF exert a dispersive effect, producing a larval advection out of the African populations of benthic species, but eddies can also concentrate larvae swept offshore from the Canaries and African populations. The interaction between filaments and the eddy field shed by the islands determines the fate of the larvae. Using a minimum planktonic larval duration of 15 days in our simulations, we were able to backtrack the pathway from the selected oceanic region south of GC to Fuerteventura Island and the African coast. It is expected that using longer planktonic larval periods of 20-30 days or even several months, the source of larvae could be located in further regions in both African and Canary populations. However, we did not perform this because our main goal was to demonstrate that in oceanic regions off the $\mathrm{C}$-ACTZ there is a mixing of larvae with different origin, and then support the in situ observations. With a 15-day experiment we achieved this goal.

\section{Retention over the continental shelf}

Studies of larval distributions conducted in the upwelling systems off California (Morgan et al. 2009), Humboldt (Yannicelli et al. 2006) and Portugal (dos Santos et al. 2008) were consistent with the present results, describing how the larvae of shelf crustacean species were widely distributed over the continental shelf, but never far from the upwelling front, while those of inshore species were found much closer to the coast. However, these studies are not completely comparable with ours because in our study the lack of sampling in areas closer than $5 \mathrm{~km}$ to shore prevented the complete observation of the African larvae distributions. We found transport to long distances more than 100 $\mathrm{km}$ offshore, but the low densities suggest that only some larvae were affected by the filament transport. The FAX99 cruise included only two shallow stations (LS24, D2) located $20 \mathrm{~km}$ from the coast, but the results also suggest larval retention over the African shelf when filaments are present. This was the case of the larvae of the neritic species Pisidia longicornis (Fig. 5), Palaemon elegans and P. serratus, which were present only over bottom depths of less than $100 \mathrm{~m}$, inside the upwelling front. Differences in larval advection patterns among nearshore species cannot be explained by environmental forcing because they are all exposed to the same physical processes. Diel and/or ontogenetic vertical migration behaviours have been stated as key factors for larval retention in upwelling areas (Queiroga and Blanton 2005, dos Santos et al. 2008, Morgan et al. 2009). We observed a vertical distribution pattern in which most of the larvae were concentrated in the upper $60 \mathrm{~m}$, with little evidence of DVM. The distribution of larvae is in the range of the vertical extension of the filament structure, so DVM might not influence the transport, because the larvae cannot reach layers with different horizontal currents. This is in accordance with our simulations but in contrast to previous modelling studies in the C-ACTZ for fish larvae, which displayed a larger effect of the DVM on transport patterns (Brochier et al. 2008).

However, we should point out that our sampling strategy was not specifically designed for that purpose (Rodríguez et al. 2006). Samples were collected at different times of the day and night and at different locations with quite different environmental conditions, thus preventing sample comparisons. Moreover, most decapod larvae were distributed in the upper layers, but the thickness of the sampling strata seems to exceed the migration range of the decapods. Also important is that the low mean larval abundance observed in the present study did not allow any accurate estimation of the migration amplitude. In the future, new studies in the C-ACTZ are needed to quantify the effect of UF on the African populations, and their role in the loss of potential recruits and therefore in the crustacean populations. Improvements in the sampling design will help to understand retention and dispersive processes modulated by the complex oceanographic field and larval behaviour.

\section{Implications for population connectivity}

UF can lead to an African connection with the marine biota of the Canary Islands, serving to maintain a unidirectional genetic flow towards the Canary Island populations. It is true that the relatively low larval abundance in the C-ACTZ implies a lower recruitment success, but if we consider that larval pulses are constant year-round (Barton et al. 1998, Brochier et al. 2011) and that population connectivity is governed by both evolutionary and ecological time-scales, the dispersal potential should increase significantly. Moreover, other factors such as the planktonic larval duration (PLD) can determine the gene flow since it confers larger or lower dispersal ability (Weersing and Toonen 2009). In this sense, population genetics have revealed panmixia (populations are extensively demographically connected) across the Macaronesian populations of the slipper lobster Scyllarides latus with a maximum PLD of 9-11 months (Faria et al. 2013). However, recent studies on species with shorter PLD, such as the striped soldier shrimp Plesionika edwardsii and the sally lightfoot crab Grapsus adscensionis, have shown significant genetic differentiation between archipelagos (Quinteiro et al. 2012), suggesting that the PLD have a key role in the connectivity. Our simulations of only 15 days of backward transport suggest a high mixing level, but unfortunately there are no data about the genetic relationships of the African and Canary populations of crustacean decapods for comparison. Notwithstanding, we consider that eddies and filaments have been playing a major function in the colonization of the archipelago, not only for the marine biota but also for the terrestrial one, since oceanic rafting has been one of the most widespread dispersal mechanism (Whittaker and Fernández-Palacios 2007). Our observations on larval transport can introduce new insights for the "mainlandto-island" general colonization model (MacArthur and Wilson 1967), and for current emerging hypotheses for 
oceanic islands biogeography (Heaney 2007), in which "island-to-mainland" reverse colonization might be more frequent than is commonly assumed. The reverse colonization pathway has been reported already from the Canary Islands to the Africa continent for plants and insects and has been suggested for lizards (Juan et al. 2000). It is likely that the complex filament-eddies interaction in the C-ACTZ may aid this reverse colonization pattern, but further studies are desirable to test this new hypothesis.

\section{ACKNOWLEDGEMENTS}

This work was supported through the projects CANIGO, MAS3.CT96-0060 (EU) and MAFIA, CTM201239587-C04-0 (CICYT, Spain). JML was funded by an FPI fellowship (BES-2005-10960) from the European Social Fund and a postdoctoral fellowship from the Japan Society for Promotion of Science (PE16401). EM was partially supported by a post-doctoral grant from the Conselleria d'Educació, Cultura i Universitats del Govern de les Illes Balears (Mallorca, Spain), the European Social Fund and the Copernicus Marine Environment Monitoring Service (CMEMS) MedSUB project. TB was funded by the AWA project "Ecosystem Approach to the management of fisheries and the marine environment in West African waters" funded by the BMBF and IRD (grant agreement 01DG12073E), and by the project PREFACE funded by the European Commission's Seventh Framework Programme (20072013) - Cooperation (ENV.2013.6.1-1), under Grant Agreement number 603521. The Pathfinder $4 \mathrm{~km}$ data were provided by GHRSST and the US National Oceanographic Data Centre. This project was supported in part by a grant from the NOAA Climate Data Record (CDR) programme for satellites. Many thanks are due to JM Rodríguez for his useful comments and help with the processing of the LHPR data.

\section{REFERENCES}

Anger K. 2001. The Biology of Decapod Crustacean Larvae. Crustacean Issues: 14. A.A. Balkema Publishers.

Arístegui J., Tett P., Hernández-Guerra A., et al. 1997. The influence of island-generated eddies on chlorophyll distribution: A study of mesoscale variation around Gran Canaria. Deep-Sea Res. I 44: 71-96. https://doi.org/10.1016/S0967-0637(96)00093-3

Atlas R., Hoffman R.N., Ardizzone J., et al. 2011. A cross-calibrated, multiplatform ocean surface wind velocity product for meteorological and oceanographic applications. Bull. Am. Meteor. Soc. 92: $157-174$. https://doi.org/10.1175/2010BAMS2946.1

Baltar F., Arístegui J., Montero M.F., et al. 2009. Mesoscale variability modulates seasonal changes in the trophic structure of nano- and picoplankton communities across the NW AfricaCanary Islands transition zone. Prog. Oceanogr. 83: 180-188. https://doi.org/10.1016/j.pocean.2009.07.016

Baltar F., Arístegui J., Gasol J.M., et al. 2010. Mesoscale eddies: hotspots of prokaryotic activity and differential community structure in the ocean. ISME J. 4: 975-988. https://doi.org/10.1038/ismej.2010.33

Barton E.D., Arístegui J., Tett P., et al. 1998. The transition zone of the Canary Current upwelling region. Prog. Oceanogr. 41: 455-504. https://doi.org/10.1016/S0079-6611(98)00023-8

Barton E.D., Basterretxea G., Flament P., et al. 2000. Lee region of Gran Canaria. J. Geophys. Res. 105: 17173-17193.
https://doi.org/10.1029/2000JC900010

Barton E.D., Arístegui J., Tett P., et al. 2004. Variability in the Canary Islands area of filament-eddy exchanges. Prog. Oceanogr. 62: 71-94 https://doi.org/10.1016/j.pocean.2004.07.003

Basterretxea G., Barton E.D., Tett P., et al. 2002. Eddy and DCM response to wind shear in the lee of Gran Canaria. Deep-Sea Res. I, 49: 1087-1101. https://doi.org/10.1016/S0967-0637(02)00009-2

Bécognée P., Almeida C., Barrera A., et al. 2006. Annual cycle of clupeiform larvae around Gran Canaria island, Canary Islands. Fish. Oceanogr. 15: 293-300. https://doi.org/10.1111/j.1365-2419.2005.00390.x

Bécognée P., Moyano M., Almeida C., et al. 2009. Mesoscale distribution of clupeoid larvae in an upwelling filament trapped by a quasi-permanent cyclonic eddy off Northwest Africa. Deep-Sea Res. I 56: 330-343. https://doi.org/10.1016/j.dsr.2008.10.008

Bordes F., Uiblein F., Castillo R., et al. 1999. Epi- and mesopelagic fishes, acoustic data, and SST images collected off Lanzarote, Fuerteventura and Gran Canaria, Canary Islands, during Cruise 'La Bocaina 04-97', Inf. Téc. Inst. Can. Cien. Mar. 5: 45 pp.

Brochier T., Ramzi A., Lett C., et al. 2008. Modelling sardine and anchovy ichthyoplankton transport in the Canary Current System. J. Plankton Res. 30: 1133-1146. https://doi.org/10.1093/plankt/fbn066

Brochier T., Mason E., Moyano M., et al. 2011. Ichthyoplankton transport from the African coast to the Canary Islands. J. Mar. Syst. 89: 109-122. https://doi.org/10.1016/j.jmarsys.2011.02.025

Capet X.J., Colas F., Penven P., et al. 2008. Ocean Modeling in an Eddying Regime in Eddies, In: Hecht M., Hasumi H. (eds) Eastern Boundary Subtropical Upwelling Systems. Geophys. Res. Lett. 177: 131-147.

Carton J.A., Giese B.S. 2008. A Reanalysis of Ocean Climate Using Simple Ocean Data Assimilation (SODA). Mon. Weather Rev. 136: $2999-3017$ https://doi.org/10.1175/2007MWR1978.1

Casey K.S., Brandon T.B., Cornillon P., et al. 2010. The Past, Present and Future of the AVHRR Pathfinder SST Program, In: Barale V., Gower J.F.R., Alberotanza L. (eds) Oceanography from Space: Revisited. Springer. pp. 273-287. https://doi.org/10.1007/978-90-481-8681-5 16

Clarke K. 1993. Non-parametric multivariate analyses of changes in community structure. Aust. J. Ecol. 18: 117-143. https://doi.org/10.1111/j.1442-9993.1993.tb00438.x

Clarke K., Warwick R. 2001. Change in Marine Communities: An Approach to Statistical Analysis and Interpretation. 2nd edition: PRIMER-E, Plymouth.

Clarke K., Gorley R. 2006. PRIMER v6: user manual/tutorial. PRIMER-E Ltd., Plymouth.

Colas F., Capet X., McWilliams J.C., et al. 2013. Mesoscale Eddy Buoyancy Flux and Eddy-Induced Circulation in Eastern Boundary Currents. J. Phys. Oceanogr. 43: 1073-1095. https://doi.org/10.1175/JPO-D-11-0241.1

Connolly S.R., Menge B.A., Roughgarden J. 2001. A latitudinal gradient in recruitment of intertidal invertebrates in the northeast Pacific Ocean. Ecology 82: 1799-1813. https://doi.org/10.1890/0012-9658(2001)082[1799:ALGIRO]2 .0. $\mathrm{CO} ; 2$

d'Udekem d'Acoz C. 1999. Inventaire et distribution des crustacés décapodes de l'Atlantique oriental, de la Méditerranée et des eaux continentales au nord de $25^{\circ} \mathrm{N}$. Collection Patrimoines Naturels, 40: i-x + 1-383. Service du Patrimoine Naturel, Muséum National d'Histoire Naturelle, Paris.

De Grave S., Pentcheff N.D., Ahyong S.T., et al. 2009. A classification of living and fossil genera of decapod crustaceans. Raffles B. Zool. 21: 1-109.

Dos Santos A., Lindley J.A. 2001. Crustacea Decapoda: Larvae. II Dendrobranchiata. (Aristeidae, Benthesicymidae, Penaeidae, Solenoceridae, Sicyonidae, Sergestidae and Luciferidae). ICES Identif. Leafl. Plankton 186.

Dos Santos A., González-Gordillo J.I. 2004. Illustrated key for the identification of the Pleocyemata (Crustacea: Decapoda) zoeal stages, from the coastal region of south-western Europe. J. Mar. Biol. Assoc. U.K. 84: 205-227. https://doi.org/10.1017/S0025315404009075h

Dos Santos A., Santos A.M.P., Conway D.V.P., et al. 2008. Diel vertical migration of decapod larvae in the Portuguese coastal upwelling ecosystem: implications for offshore transport. Mar. 
Ecol. Prog. Ser. 359: 171-183. https://doi.org/10.3354/meps07341

Dufois F., Penven P., Whittle C.P., et al. 2012. On the warm nearshore bias in Pathfinder monthly SST products over Eastern Boundary Upwelling Systems. Ocean Model. 47: 113-118. https://doi.org/10.1016/j.ocemod.2012.01.007

Faria J., Froufe E., Tuya F., et al. 2013. Panmixia in the endangered slipper lobster Scyllarides latus from the Northeastern Atlantic and Western Mediterranean. J. Crust. Biol. 33: 557-566. https://doi.org/10.1163/1937240X-00002158

Foxton P. 1970a. The vertical distribution of Pelagic Decapods (Crustacea: Natantia) collected on the Sond Cruise, 1965 I. The Caridea. J. Mar. Biol. Assoc. U.K. 50: 939-960. https://doi.org/10.1017/S0025315400005907

Foxton P. 1970b. The vertical distribution of Pelagic Decapods (Crustacea: Natantia) collected on the Sond Cruise, 1965 II. The Penaeidea and general discussion. J. Mar. Biol. Assoc. U.K. 50: 961-1000. https://doi.org/10.1017/S0025315400005919

García-Muñoz M., Arístegui J., Montero M.F., et al. 2004. Distribution of organic matter along a filament-eddy system in the Canaries-NW Africa coastal transition zone region. Prog. Oceanogr. 62: 115-129. https://doi.org/10.1016/j.pocean.2004.07.005

González-Gordillo J.I., dos Santos A., Rodríguez A. 2001. Checklist and annotated bibliography of decapod crustacean larvae from the Southwestern European coast (Gibraltar Strait area). Sci. Mar. 65: 275-305. https://doi.org/10.3989/scimar.2001.65n4275

Heaney L.R. 2007. Is a new paradigm emerging for oceanic island biogeography? J. Biogeogr. 34: 753-757 https://doi.org/10.1111/j.1365-2699.2007.01692.x

Hernández-Guerra A., Arístegui J., Cantón M., et al. 1993. Phytoplankton pigment patterns in the Canary Islands area as determined using coastal zone colour scanner data. Int. J. Remote Sens. 14: 1431-1437 https://doi.org/10.1080/01431169308953977

Hernández-León S., Almeida C., Gómez M., et al. 2001a. Zooplankton biomass and indices of feeding and metabolism in island-generated eddies. J. Mar. Syst. 30: 51-66. https://doi.org/10.1016/S0924-7963(01)00037-9

Hernández-León S., Almeida C., Yebra L., et al. 2001b. Zooplankton abundance in subtropical waters: is there a lunar cycle? Sci. Mar. 65: 59-64 https://doi.org/10.3989/scimar.2001.65s159

Hernández-León S., Almeida C., Portillo-Hahnefeld A, et al. 2002a. Zooplankton biomass and indices of feeding and metabolism in relation to an upwelling filament off northwest Africa. J. Mar. Res. 60: 327-346. https://doi.org/10.1357/00222400260497516

Hernández-León S., Almeida C., Yebra L., et al. 2002b. Lunar cycle of zooplankton biomass in subtropical waters: biogeochemical implications. J. Plankton Res. 24: 935-939. https://doi.org/10.1093/plankt/24.9.935

Hopkins T.L., Gartner J.V. 1992. Resource-partitioning and predation impact of a low-latitude myctophid community. Mar. Biol. 114: $185-197$ https://doi.org/10.1007/BF00349518

Jiménez B., Sangrà P., Mason E. 2008. A numerical study of the relative importance of wind and topographic forcing on oceanic eddy shedding by tall, deep water islands. Ocean Model. 22: 146-157. https://doi.org/10.1016/j.ocemod.2008.02.004

Joachimiak M.P., Weissman J.L., May B.C.H. 2006. JColorGrid: software for the visualization of biological measurements. BMC Bioinform. 7: 225-230. https://doi.org/10.1186/1471-2105-7-225

Jones B.H., Mooers C.N.K., Rienecker M.M., et al. 1991. Chemical and biological structure and transport of a cool filament associated with a jet-eddy system off northern California in July 1986 (OPTOMA21). J. Geophys. Res. 96 (C12): 22207-22225. https://doi.org/10.1029/91JC02146

Juan C., Emerson B., Oromí I., et al. 2000. Colonization and diversification: towards a phylogeographic synthesis for the Canary Islands. Trends Ecol. Evol. 15: 104-109. https://doi.org/10.1016/S0169-5347(99)01776-0

Landeira J.M., Lozano-Soldevilla F. Hernández-León S., et al. 2009. Horizontal distribution of invertebrate larvae around the oceanic island of Gran Canaria: the effect of mesoscale variability. Sci. Mar. 73: 757-767. https://doi.org/10.3989/scimar.2009.73n4757

Landeira J.M., Lozano-Soldevilla F., Hernández-León S., et al. 2010. Spatial variability of planktonic invertebrate larvae in the Canary Islands area. J. Mar. Biol. Assoc. U.K. 90: 1217-1225. https://doi.org/10.1017/S0025315409990750

Landeira J.M., Lozano-Soldevilla F., Barton E.D. 2012. Mesoscale advection of Upogebia pusilla larvae through an upwelling filament in the Canaries CTZ. Helgol. Mar. Res. 66: 537-544. https://doi.org/10.1007/s10152-011-0289-5

Lasternas S., Piedeleu M., Sangrà P., et al. 2013. Forcing of dissolved organic carbon release by phytoplankton by anticyclonic mesoscale eddies in the subtropical NE Atlantic Ocean. Biogeoscience 10: 2129-2143 https://doi.org/10.5194/bg-10-2129-2013

Lett C., Verley P., Mullon C., et al. 2008. A Lagrangian tool for modelling ichthyoplankton dynamics. Env. Model. Softw. 23: 1210-1214. https://doi.org/10.1016/j.envsoft.2008.02.005

Lobel P.S., Robinson A.R. 1988. Larval fishes and zooplankton in a cyclonic eddy in Hawaiian waters. J. Plankton Res. 10: 1209-1223. https://doi.org/10.1093/plankt/10.6.1209

MacArthur R.H., Wilson E.O. 1967. The theory of island biogeography, Princeton Univ. Press.

Mace A.J., Morgan S.G. 2006. Larval accumulation in the lee of a small headland: implications for the design of marine reserves. Mar. Ecol. Progr. Ser. 318: 19-29. https://doi.org/10.3354/meps318019

Marchesiello P., Estrade P. 2009. Eddy activity and mixing in upwelling systems: a comparative study of Northwest Africa and California regions. Int. J. Earth Sci. 98: 299-308. https://doi.org/10.1007/s00531-007-0235-6

Mason E., Molemaker M.J., Colas F., et al. 2010. Procedures for offline grid nesting in regional ocean models. Ocean Model. 35: $1-15$. https://doi.org/10.1016/j.ocemod.2010.05.007

Mason E., Colas F., Molemaker M.J., et al. 2011. Seasonal variability of the Canary Current: a numerical study. J. Geophys. Res. 116: C00601. https://doi.org/10.1029/2010JC006665

Morgan S.G, Fisher J. 2010. Larval behavior regulates nearshore retention and offshore migration in an upwelling shadow and along the open coast. Mar. Ecol. Prog. Ser. 404: 109-126. https://doi.org/10.3354/meps08476

Morgan S.G, Fisher J., Miller S., et al. 2009. Nearshore larval retention in a region of strong upwelling and recruitment limitation. Ecology 90: 3489-3502. https://doi.org/10.1890/08-1550.1

Moyano M., Rodríguez J.M., Hernández-León S. 2009. Larval fish abundance and distribution during the late winter bloom off Gran Canaria Island, Canary Islands. Fish. Oceanogr. 18: 51-61. https://doi.org/10.1111/j.1365-2419.2008.00496.x

Navarrete S.A., Wieters E.A., Broitman B.R., et al. 2005. Scales of benthic-pelagic coupling and the intensity of species interactions: from recruitment limitation to top-down control. Proc. Natl. Acad. Sci. U.S.A. 102: 18046-18051. https://doi.org/10.1073/pnas.0509119102

Palma A.T., Pardo L.M., Veas R.I., et al. 2006. Coastal brachyuran decapods: settlement and recruitment under contrasting coastal geometry conditions. Mar. Ecol. Prog. Ser. 316: 139-153. https://doi.org/10.3354/meps316139

Penven P., Echevin V., Pasapera J., et al. 2005. Average circulation, seasonal cycle, and mesoscale dynamics of the Peru Current System: A modeling approach. J. Geophys. Res. 110 (C10): 021. https://doi.org/10.1029/2005JC002945

Piedeleu M., Sangrà P., Sánchez-Vidal A., et al. 2009. An observational study of oceanic eddy generation mechanisms by tall deep-water islands (Gran Canaria). Geophys. Res. Lett. 36: L14605. https://doi.org/10.1029/2008GL037010

Pineda J., Hare J.A., Sponaugle S. 2007. Larval transport and dispersal in the coastal ocean and consequences for population connectivity. Oceanography 20: 22-39. https://doi.org/10.5670/oceanog.2007.27

Queiroga H., Blanton J. 2005. Interactions between behaviour and physical forcing in the control of horizontal transport of decapod crustacean larvae. Adv. Mar. Biol. 47: 107-214. https://doi.org/10.1016/S0065-2881(04)47002-3

Quinteiro J., Manent P., González N., et al. 2012. Red BANGEMAC: 
Banco genético marino de Macaronesia.

Rodríguez J.M., Hernández S., Barton E.D. 1999. Mesoscale distribution of fish larvae in relation to an upwelling filament off Northwest Africa. Deep-Sea Res. I 46: 1969-1984. https://doi.org/10.1016/S0967-0637(99)00036-9

Rodríguez J.M., Barton E.D., Eve L., et al. 2001. Mesozooplankton and ichthyoplankton distribution around Gran Canaria, an oceanic island in the NE Atlantic. Deep-Sea Res. I 48: 2161-2183. https://doi.org/10.1016/S0967-0637(01)00013-9

Rodríguez J.M., Barton E.D., Hernández-León S., et al. 2004. The influence of mesoscale physical processes on the larval fish larvae community in the Canaries-CTZ, in summer. Prog. Oceanogr. 62: 171-188 https://doi.org/10.1016/j.pocean.2004.07.006

Rodríguez J.M., Hernández-León S., Barton E.D. 2006. Vertical distribution of fish larvae in the Canaries CTZ, in summer. Mar. Biol. 149: 885-897. https://doi.org/10.1007/s00227-006-0270-z

Rodríguez J.M., Moyano M., Hernández-León S. 2009. The ichthyoplankton assemblage of the Canaries-African Coastal Transition Zone: A review. Prog. Oceanogr. 83: 314-321. https://doi.org/10.1016/j.pocean.2009.07.009

Roughgarden J., Gaines S., Possingham H. 1988. Recruitment dynamics in complex life cycles. Science 241: 1460-1466. https://doi.org/10.1126/science.11538249

Saha S., Moorthi S., Pan H.-L., et al. 2010. The NCEP Climate Forecast System Reanalysis. Bull. Am. Meteor. Soc. 91: 1015-1057. https://doi.org/10.1175/2010BAMS3001.1

Sangrà P., Basterretxea G., Pelegrí J.L., et al. 2001. Chlorophyll increase due to internal waves on the shelf break of Gran Canaria (Canary Islands). Sci. Mar. 65 (Suppl. 1): 89-97. https://doi.org/10.3989/scimar.2001.65s189

Sangrà P., Auladell M., Marrero-Díaz A., et al. 2007. On the nature of oceanic eddies shed by the Island of Gran Canaria. Deep-Sea Res. I 54: 687-709. https://doi.org/10.1016/j.dsr.2007.02.004

Sangrà P., Pascual A., Rodríguez-Santana Á., et al. 2009. The Canary Eddy Corridor: a major pathway for long-lived eddies in the subtropical North Atlantic. Deep-Sea Res. I 54: 2100-2114. https://doi.org/10.1016/j.dsr.2009.08.008

Santana-Falcón Y., Benavides M., Sangrà P., et al. 2016. Coastaloffshore exchange of organic matter across the Cape Ghir filament (NW Africa) during moderate upwelling. J. Mar. Syst. 154: $233-242$ https://doi.org/10.1016/j.jmarsys.2015.10.008

Shanks A.L., Shearman R.K. 2009. Paradigm lost? Cross-shelf distributions of intertidal invertebrate larvae are unaffected by upwelling or downwelling. Mar. Ecol. Prog. Ser. 385: 189-204. https://doi.org/10.3354/meps08043

Shchepetkin A.F., McWilliams J.C. 2005. The Regional Oceanic Modeling System (ROMS): a split-explicit, free-surface, topography-following-coordinate oceanic model. Ocean Modell. 9: 347-404.

https://doi.org/10.1016/j.ocemod.2004.08.002

Shchepetkin A.F., McWilliams J.C. 2009. Correction and commentary for "Ocean forecasting in terrain-following coordinates: formulation and skill assessment of the regional ocean modeling system" by Haidvogel et al., J. Comp. Phys. 227: 3595-3624, J. Comput. Phys. 228: 8985-9000. https://doi.org/10.1016/j.jcp.2009.09.002

Smith S.D. 1988. Coefficients for sea surface wind stress, heat flux, and wind profiles as a function of wind speed and temperature. J. Geophys. Res. 93: 15467-15472. https://doi.org/10.1029/JC093iC12p15467

Torres A.P., dos Santos A., Balbín R., et al. 2014. Decapod crustacean larval communities in the Balearic Sea (western Mediterranean): seasonal composition, horizontal and vertical distribution patterns. J. Mar. Syst. 138: 112-126. https://doi.org/10.1016/j.jmarsys.2013.11.017

Underwood A.J., Keough M.J. 2001. Supply-side ecology: the nature and consequences of variations in recruitment of intertidal organisms. In: Bertness M.D., Gaines S.D., Hay M.E. (eds). Marine community ecology. Sinauer, Sunderland, Massachusetts, pp. 183-200.

Veitch J., Penven P., Shillington F. 2010. Modeling equilibrium dynamics of the Benguela Current System. J. Phys. Oceanogr. 40: 1942-1964. https://doi.org/10.1175/2010JPO4382.1

Weersing K., Toonen R.J. 2009. Population genetics, larval dispersal, and connectivity in marine systems. Mar. Ecol. Prog. Ser. 393: $1-12$. https://doi.org/10.3354/meps08287

Wing S.R., Botsford L., Ralston J.S.V. et al. 1998. Meroplanktonic distribution and circulation in a coastal retention zone of the northern California upwelling system. Limnol. Oceanogr. 43: 1710-1721. https://doi.org/10.4319/1o.1998.43.7.1710

Whittaker R.J., Fernández-Palacios J.M. 2007. Island biogeography: ecology, evolution, and conservation. Oxford Univ. Press.

Yannicelli B., Castro L., Schneider W., et al. 2006. Crustacean larvae distribution in the coastal upwelling zone off Central Chile. Mar. Ecol. Prog. Ser. 319: 175-189. https://doi.org/10.3354/meps319175

Yebra L., Hernández-León S., Almeida C., et al. 2004. The effect of upwelling filaments and island-induced eddies on indices of feeding, respiration and growth in copepods. Prog. Oceanogr. 62: $151-169$.

https://doi.org/10.1016/j.pocean.2004.07.008

\section{SUPPLEMENTARY MATERIAL}

The following supplementary material is available through the online version of this article and at the following link: http://scimar.icm.csic.es/scimar/supplm/sm04599esm.pdf

Table S1. - List of decapod larvae collected, average values of abundance (larvae $/ 100 \mathrm{~m}^{3}$ and standard deviation), and numeric percentage in the three regions: eddy, stratified and upwelling filaments. B, benthic species. P, pelagic species. 


\section{Transport pathways of decapod larvae under intense mesoscale activity in the Canary-African coastal transition zone: implications for population connectivity}

José M. Landeira, Timothée Brochier, Evan Mason, Fernando Lozano-Soldevilla, Santiago Hernández-León, Eric D. Barton

Supplementary material 
Table S1. - List of decapod larvae collected, average values of abundance (larvae/100 $\mathrm{m}^{3}$ and standard deviation), and numeric percentage in

\begin{tabular}{|c|c|c|c|c|c|c|}
\hline & & Eddy & Stratified & $\begin{array}{l}\text { Upwelling fila- } \\
\text { ments }\end{array}$ & Total & $\%$ \\
\hline \multicolumn{7}{|l|}{ Dendrobranchiata } \\
\hline Aristaeomorpha foliacea & B & $0.21 \pm 0.56$ & & & $0.07 \pm 0.33$ & 0.21 \\
\hline Gennadas spp. & $\mathrm{P}$ & $2.93 \pm 6.42$ & $0.32 \pm 0.45$ & $0.77 \pm 1.3$ & $1.29 \pm 3.8$ & 3.99 \\
\hline Parapenaeus longirostris & B & $0.03 \pm 0.11$ & & & $0.01 \pm 0.06$ & 0.03 \\
\hline Solenocera menbranacea & B & $0.43 \pm 0.88$ & $0.1 \pm 0.21$ & $0.69 \pm 0.86$ & $0.36 \pm 0.7$ & 1.13 \\
\hline Lucifer typus & $\mathrm{P}$ & $0.52 \pm 0.76$ & & & $0.17 \pm 0.49$ & 0.52 \\
\hline Allosergestes pectinatus & $\mathrm{P}$ & $0.57 \pm 1.04$ & $0.02 \pm 0.09$ & $0.53 \pm 1.67$ & $0.34 \pm 1.05$ & 1.04 \\
\hline Allosergestes sargassi & $\mathrm{P}$ & $0.27 \pm 0.54$ & $0.37 \pm 1.3$ & $0.39 \pm 0.72$ & $0.34 \pm 0.94$ & 1.06 \\
\hline Deosergestes curvatus & $\mathrm{P}$ & $0.24 \pm 0.7$ & & $0.06 \pm 0.19$ & $0.09 \pm 0.41$ & 0.29 \\
\hline Deosergestes henseni & $\mathrm{P}$ & $2.82 \pm 2.85$ & $0.2 \pm 0.48$ & $0.28 \pm 0.46$ & $1.07 \pm 2.03$ & 3.32 \\
\hline Parasergestes diaponticus & $\mathrm{P}$ & $0.65 \pm 2.02$ & $0.05 \pm 0.14$ & $0.1 \pm 0.3$ & $0.26 \pm 1.16$ & 0.80 \\
\hline Parasergestes vigilax & $\mathrm{P}$ & $2.09 \pm 2.71$ & $1.23 \pm 2.1$ & $1.19 \pm 2.17$ & $1.5 \pm 2.31$ & 4.64 \\
\hline Sergestes atlanticus & $\mathrm{P}$ & $0.25 \pm 0.46$ & $0.25 \pm 0.58$ & $1.06 \pm 2.42$ & $0.47 \pm 1.34$ & 1.45 \\
\hline Sergestes cornutus & $\mathrm{P}$ & $0.04 \pm 0.13$ & & & $0.01 \pm 0.07$ & 0.04 \\
\hline Sergia robusta & $\mathrm{P}$ & $0.61 \pm 1.2$ & $0.08 \pm 0.23$ & $0.11 \pm 0.34$ & $0.26 \pm 0.74$ & 0.81 \\
\hline Sergia japonica & $\mathrm{P}$ & $0.04 \pm 0.13$ & & & $0.01 \pm 0.07$ & 0.04 \\
\hline Sergia splendens & $\mathrm{P}$ & $0.18 \pm 0.47$ & & & $0.06 \pm 0.27$ & 0.18 \\
\hline Sergestidae spp. & $\mathrm{P}$ & $1.83 \pm 2.11$ & $0.94 \pm 1.44$ & $1.79 \pm 4.01$ & $1.46 \pm 2.53$ & 4.51 \\
\hline \multicolumn{7}{|l|}{ Pleocyemata } \\
\hline Stenopus spinosus & B & $0.19 \pm 0.39$ & $0.24 \pm 0.37$ & $0.26 \pm 0.44$ & $0.23 \pm 0.39$ & 0.70 \\
\hline Stenopus spp. & B & & $0.03 \pm 0.14$ & & $0.01 \pm 0.09$ & 0.04 \\
\hline Acanthephyra purpurea & $\mathrm{P}$ & $0.45 \pm 0.89$ & $0.18 \pm 0.38$ & $0.4 \pm 0.75$ & $0.33 \pm 0.67$ & 1.01 \\
\hline Acanthephyra spp. & $\mathrm{P}$ & $0.43 \pm 0.53$ & $0.49 \pm 0.71$ & $0.31 \pm 0.8$ & $0.42 \pm 0.67$ & 1.31 \\
\hline Systellaspis spp. & $\mathrm{P}$ & & $0.02 \pm 0.08$ & $0.07 \pm 0.23$ & $0.03 \pm 0.13$ & 0.09 \\
\hline Oplophoridae spp. & $\mathrm{P}$ & $0.37 \pm 0.61$ & $0.03 \pm 0.11$ & $0.23 \pm 0.4$ & $0.19 \pm 0.43$ & 0.59 \\
\hline Nematocarcinus spp. & $\mathrm{P}$ & $0.12 \pm 0.25$ & $0.08 \pm 0.22$ & & $0.07 \pm 0.2$ & 0.22 \\
\hline Brachycarpus biungiculatus & B & $0.03 \pm 0.11$ & & & $0.01 \pm 0.06$ & 0.03 \\
\hline Palaemon serratus & B & & & $0.11 \pm 0.34$ & $0.03 \pm 0.18$ & 0.09 \\
\hline Palaemon elegans & B & & & $0.15 \pm 0.48$ & $0.04 \pm 0.25$ & 0.13 \\
\hline Palaemonidae spp. & $\mathrm{B}$ & $0.09 \pm 0.3$ & $0.07 \pm 0.25$ & & $0.05 \pm 0.23$ & 0.17 \\
\hline Periclimenes spp. & B & $0.13 \pm 0.24$ & $0.2 \pm 0.4$ & & $0.12 \pm 0.29$ & 0.38 \\
\hline Pontoniinae spp. & $\mathrm{B}$ & $0.44 \pm 0.4$ & & & $0.14 \pm 0.31$ & 0.44 \\
\hline Alpheus macrocheles & $\mathrm{B}$ & & $0.15 \pm 0.45$ & $0.14 \pm 0.35$ & $0.1 \pm 0.34$ & 0.30 \\
\hline Alpheus glaber & B & $1.08 \pm 0.85$ & $0.46 \pm 0.76$ & $0.8 \pm 0.81$ & $0.75 \pm 0.83$ & 2.33 \\
\hline Alpheus spp. & B & $0.23 \pm 0.54$ & $0.18 \pm 0.37$ & $0.29 \pm 0.71$ & $0.23 \pm 0.52$ & 0.70 \\
\hline Athanas nitescens & B & $0.3 \pm 0.53$ & $0.18 \pm 0.27$ & $0.55 \pm 0.7$ & $0.32 \pm 0.51$ & 0.99 \\
\hline Eualus occultus & B & $0.03 \pm 0.09$ & $0.03 \pm 0.12$ & $0.54 \pm 1.7$ & $0.17 \pm 0.88$ & 0.51 \\
\hline Eualus sp. & B & & & $0.08 \pm 0.24$ & $0.02 \pm 0.12$ & 0.06 \\
\hline Lysmata seticaudata & B & $0.31 \pm 0.41$ & $0.19 \pm 0.3$ & $0.7 \pm 1.16$ & $0.37 \pm 0.68$ & 1.13 \\
\hline Hippolyte spp. & $\mathrm{B}$ & & & $0.45 \pm 1.43$ & $0.12 \pm 0.74$ & 0.38 \\
\hline Hippolytidae spp. & B & $0.09 \pm 0.3$ & $0.03 \pm 0.11$ & & $0.04 \pm 0.18$ & 0.12 \\
\hline Latreutes fucorum & $\mathrm{B}$ & $0.04 \pm 0.14$ & & & $0.01 \pm 0.08$ & 0.04 \\
\hline Processa modica & B & $0.05 \pm 0.17$ & & & $0.02 \pm 0.1$ & 0.05 \\
\hline Processa nouvel holthuisi & $\mathrm{B}$ & $0.35 \pm 0.65$ & $0.11 \pm 0.24$ & $0.97 \pm 2.41$ & $0.42 \pm 1.31$ & 1.29 \\
\hline Processa edulis crassipes & B & $0.16 \pm 0.38$ & $0.17 \pm 0.42$ & $3.66 \pm 8.18$ & $1.11 \pm 4.4$ & 3.44 \\
\hline Processa EM6 & B & & $0.06 \pm 0.16$ & & $0.02 \pm 0.1$ & 0.07 \\
\hline Processa sp A & B & & $0.14 \pm 0.25$ & $0.5 \pm 0.92$ & $0.19 \pm 0.53$ & 0.59 \\
\hline Processa $\mathrm{sp}$ & B & $0.11 \pm 0.2$ & $0.08 \pm 0.23$ & $0.25 \pm 0.49$ & $0.13 \pm 0.31$ & 0.42 \\
\hline Pandalina brevirostris & $\mathrm{B}$ & $0.06 \pm 0.14$ & $0.14 \pm 0.21$ & $0.15 \pm 0.48$ & $0.12 \pm 0.29$ & 0.36 \\
\hline Plesionika edwardsi & $\mathrm{B}$ & $0.64 \pm 0.67$ & $0.27 \pm 0.55$ & $0.06 \pm 0.19$ & $0.33 \pm 0.57$ & 1.03 \\
\hline Plesionika narval & $\mathrm{B}$ & $0.82 \pm 1.42$ & $0.32 \pm 0.51$ & $0.78 \pm 0.9$ & $0.61 \pm 0.99$ & 1.88 \\
\hline Plesionika spp. & $\mathrm{B}$ & $0.35 \pm 0.64$ & $0.03 \pm 0.14$ & $0.14 \pm 0.35$ & $0.17 \pm 0.43$ & 0.51 \\
\hline Heterocarpus spp. & B & $0.03 \pm 0.09$ & & & $0.01 \pm 0.05$ & 0.03 \\
\hline Pandalidae spp. & $\mathrm{B}$ & $0.05 \pm 0.11$ & $0.06 \pm 0.16$ & $0.28 \pm 0.53$ & $0.12 \pm 0.31$ & 0.36 \\
\hline Aegaeon cataphractus & B & & $0.05 \pm 0.18$ & $0.15 \pm 0.48$ & $0.06 \pm 0.27$ & 0.19 \\
\hline Philocheras sculptus & B & $0.1 \pm 0.33$ & & $0.79 \pm 2.13$ & $0.24 \pm 1.13$ & 0.75 \\
\hline Philocheras bispinosus & B & & & $0.15 \pm 0.48$ & $0.04 \pm 0.25$ & 0.13 \\
\hline Upogebia spp. & B & & & $1 \pm 2.35$ & $0.27 \pm 1.26$ & 0.84 \\
\hline Callianassidae SL16 & $\mathrm{B}$ & $1.7 \pm 2.14$ & $2.91 \pm 3.44$ & $3.08 \pm 2.77$ & $2.57 \pm 2.88$ & 7.94 \\
\hline Palinurus spp. & $\mathrm{B}$ & & & $0.11 \pm 0.34$ & $0.03 \pm 0.18$ & 0.09 \\
\hline Scyllarus spp. & B & $0.41 \pm 0.37$ & $0.27 \pm 0.33$ & $0.21 \pm 0.36$ & $0.3 \pm 0.35$ & 0.92 \\
\hline Galathea dispersa & $\mathrm{B}$ & $0.04 \pm 0.14$ & $0.18 \pm 0.56$ & $0.64 \pm 0.86$ & $0.26 \pm 0.61$ & 0.80 \\
\hline Galathea intermedia & B & $0.16 \pm 0.26$ & $0.06 \pm 0.17$ & $1.01 \pm 2.14$ & $0.35 \pm 1.16$ & 1.08 \\
\hline Munida intermedia & B & & $0.15 \pm 0.29$ & $0.21 \pm 0.68$ & $0.12 \pm 0.39$ & 0.37 \\
\hline Munida spp. & B & $0.02 \pm 0.08$ & $0.22 \pm 0.44$ & $0.08 \pm 0.24$ & $0.12 \pm 0.31$ & 0.36 \\
\hline Pisidia longirostris & B & & & $0.23 \pm 0.72$ & $0.06 \pm 0.37$ & 0.19 \\
\hline Albunea carabus & B & $0.24 \pm 0.37$ & & & $0.08 \pm 0.23$ & 0.24 \\
\hline Diogenes pugilator & B & & & $0.11 \pm 0.34$ & $0.03 \pm 0.18$ & 0.09 \\
\hline Dardanus arrosor & $\mathrm{B}$ & $0.33 \pm 0.68$ & $0.15 \pm 0.41$ & $0.04 \pm 0.12$ & $0.18 \pm 0.48$ & 0.55 \\
\hline Calcinus tubularis & B & $3.73 \pm 3.56$ & $0.41 \pm 0.82$ & $0.23 \pm 0.6$ & $1.44 \pm 2.61$ & 4.45 \\
\hline Clibanarius aequabilis & B & $0.07 \pm 0.17$ & & & $0.02 \pm 0.1$ & 0.07 \\
\hline Nematopagurus longicornis & $\mathrm{B}$ & & & $0.04 \pm 0.12$ & $0.01 \pm 0.06$ & 0.03 \\
\hline Pagurus alatus & B & $0.02 \pm 0.07$ & $0.03 \pm 0.13$ & $0.26 \pm 0.55$ & $0.09 \pm 0.31$ & 0.28 \\
\hline Pagurus spp. & B & & & $0.58 \pm 1.39$ & $0.16 \pm 0.74$ & 0.49 \\
\hline Paromola cuvieri & $\mathrm{B}$ & & $0.03 \pm 0.12$ & & $0.01 \pm 0.08$ & 0.04 \\
\hline
\end{tabular}




\begin{tabular}{|c|c|c|c|c|c|c|}
\hline & & Eddy & Stratified & $\begin{array}{l}\text { Upwelling fila- } \\
\text { ments }\end{array}$ & Total & $\%$ \\
\hline Homola barbata & B & $0.08 \pm 0.28$ & $0.03 \pm 0.11$ & $0.21 \pm 0.36$ & $0.09 \pm 0.26$ & 0.29 \\
\hline Homolidae spp. & $\mathrm{B}$ & $0.02 \pm 0.07$ & & & $0.01 \pm 0.04$ & 0.02 \\
\hline Latreillia elegans & $\mathrm{B}$ & $0.02 \pm 0.07$ & & & $0.01 \pm 0.04$ & 0.02 \\
\hline Calappa granulata & $\mathrm{B}$ & $1.69 \pm 2.22$ & $6.79 \pm 25.67$ & $0.28 \pm 0.63$ & $3.38 \pm 16.32$ & 10.46 \\
\hline Atelecyclus spp. & B & $0.05 \pm 0.13$ & $0.21 \pm 0.81$ & $0.95 \pm 1.83$ & $0.36 \pm 1.11$ & 1.11 \\
\hline Ethusa mascarone & B & $0.04 \pm 0.15$ & $0.11 \pm 0.41$ & $0.08 \pm 0.24$ & $0.08 \pm 0.29$ & 0.24 \\
\hline Eriphia verrucosa & B & & $0.03 \pm 0.14$ & & $0.01 \pm 0.09$ & 0.04 \\
\hline Goneplax rhomboides & $\mathrm{B}$ & & $0.47 \pm 0.74$ & $2.95 \pm 7.24$ & $0.99 \pm 3.85$ & 3.05 \\
\hline Ilia nucleus & $\mathrm{B}$ & $0.2 \pm 0.5$ & $0.06 \pm 0.16$ & $0.16 \pm 0.39$ & $0.13 \pm 0.36$ & 0.41 \\
\hline Ebalia tumefacta & $\mathrm{B}$ & $0.43 \pm 0.6$ & $0.08 \pm 0.23$ & $1.07 \pm 1.63$ & $0.46 \pm 0.98$ & 1.43 \\
\hline Majidae S11 & $\mathrm{B}$ & $0.09 \pm 0.18$ & $0.39 \pm 1.02$ & $0.29 \pm 0.72$ & $0.26 \pm 0.75$ & 0.82 \\
\hline Maja crispata & $\mathrm{B}$ & & & $0.12 \pm 0.38$ & $0.03 \pm 0.2$ & 0.10 \\
\hline Herbstia condiliata & $\mathrm{B}$ & $0.02 \pm 0.07$ & & $0.22 \pm 0.68$ & $0.07 \pm 0.36$ & 0.20 \\
\hline Stenorhynchus lanceolatus & $\mathrm{B}$ & & $0.21 \pm 0.8$ & & $0.08 \pm 0.51$ & 0.26 \\
\hline Majidae spp. & B & $0.29 \pm 0.54$ & $0.02 \pm 0.09$ & & $0.1 \pm 0.33$ & 0.32 \\
\hline Macropodia spp. & B & & $0.06 \pm 0.25$ & & $0.03 \pm 0.16$ & 0.08 \\
\hline Pirimela denticulata & $\mathrm{B}$ & $0.03 \pm 0.11$ & & & $0.01 \pm 0.06$ & 0.03 \\
\hline Eurynome aspera & $\mathrm{B}$ & & & $0.21 \pm 0.68$ & $0.06 \pm 0.35$ & 0.18 \\
\hline Heterocrypta maltzami & $\mathrm{B}$ & $0.08 \pm 0.26$ & & & $0.02 \pm 0.15$ & 0.08 \\
\hline Geryonidae spp. & $\mathrm{B}$ & $0.07 \pm 0.24$ & $0.02 \pm 0.09$ & $0.3 \pm 0.95$ & $0.11 \pm 0.51$ & 0.35 \\
\hline Liocarcinus corrugatus & $\mathrm{B}$ & & $0.03 \pm 0.11$ & & $0.01 \pm 0.07$ & 0.03 \\
\hline Liocarcinus spp. & $\mathrm{B}$ & & $0.5 \pm 1.82$ & $0.12 \pm 0.38$ & $0.23 \pm 1.17$ & 0.72 \\
\hline Necora puber & $\mathrm{B}$ & & & $0.06 \pm 0.19$ & $0.02 \pm 0.1$ & 0.05 \\
\hline Macropius tuberculatus & $\mathrm{B}$ & & $0.05 \pm 0.12$ & & $0.02 \pm 0.08$ & 0.06 \\
\hline Pilumnus spp. & B & & $0.03 \pm 0.13$ & & $0.01 \pm 0.08$ & 0.04 \\
\hline Xantho poressa & $\mathrm{B}$ & $1.76 \pm 1.67$ & $0.29 \pm 0.59$ & $0.29 \pm 0.41$ & $0.76 \pm 1.23$ & 2.36 \\
\hline Panopeus africanus & $\mathrm{B}$ & $0.04 \pm 0.13$ & $0.41 \pm 0.75$ & $0.61 \pm 0.96$ & $0.34 \pm 0.71$ & 1.06 \\
\hline Nanocassiope melanodactyla & $\mathrm{B}$ & $0.43 \pm 0.56$ & $0.52 \pm 1.16$ & $0.65 \pm 1.09$ & $0.52 \pm 0.96$ & 1.62 \\
\hline Percnon gibbesi & $\mathrm{B}$ & $0.19 \pm 0.28$ & $0.06 \pm 0.23$ & & $0.08 \pm 0.22$ & 0.26 \\
\hline Grapsus adscensionis & $\mathrm{B}$ & $0.09 \pm 0.32$ & $0.03 \pm 0.11$ & & $0.04 \pm 0.19$ & 0.13 \\
\hline Pachygrapsus spp. & $\mathrm{B}$ & $0.31 \pm 0.43$ & $0.23 \pm 0.91$ & & $0.2 \pm 0.63$ & 0.61 \\
\hline Plagusia depressa & $\mathrm{B}$ & $0.32 \pm 0.69$ & $0.04 \pm 0.12$ & & $0.12 \pm 0.42$ & 0.38 \\
\hline Planes minutus & $\mathrm{B}$ & & & $0.06 \pm 0.19$ & $0.02 \pm 0.1$ & 0.05 \\
\hline Grapsidae spp. & $\mathrm{B}$ & $0.07 \pm 0.18$ & $0.41 \pm 0.67$ & $0.14 \pm 0.32$ & $0.23 \pm 0.49$ & 0.71 \\
\hline Parthenope spp. & B & $0.78 \pm 1.03$ & $0.73 \pm 1.11$ & $0.72 \pm 1.3$ & $0.74 \pm 1.11$ & 2.30 \\
\hline Parthenopidae spp. & B & $1.37 \pm 1.75$ & $0.03 \pm 0.13$ & $0.14 \pm 0.44$ & $0.49 \pm 1.17$ & 1.53 \\
\hline Brachyura no id. & $\mathrm{B}$ & $1.46 \pm 1.33$ & $0.75 \pm 0.73$ & $0.35 \pm 0.52$ & $0.87 \pm 1.01$ & 2.69 \\
\hline OTAL & & $37.38 \pm 25.15$ & $24.54 \pm 39.27$ & $37.82 \pm 46.64$ & $32.29 \pm 30.68$ & \\
\hline
\end{tabular}

